Nevada

Environmental

Restoration

Project

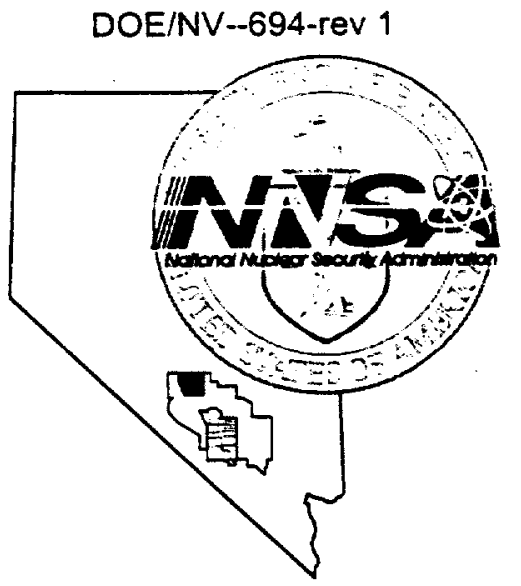

Closure Report

for Corrective Action Unit 407:

Roller Coaster RADSAFE Area,

Tonopah Test Range, Nevada

Controlled Copy No.:

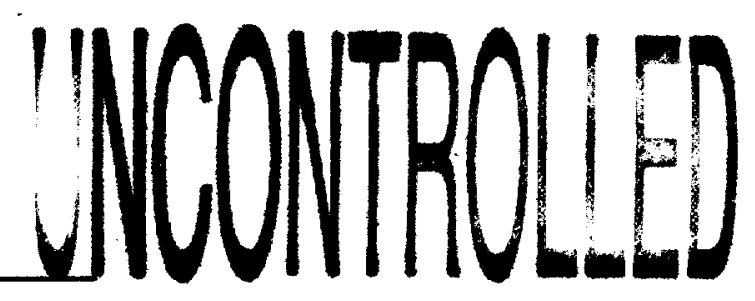

Revision: 1

December 2001

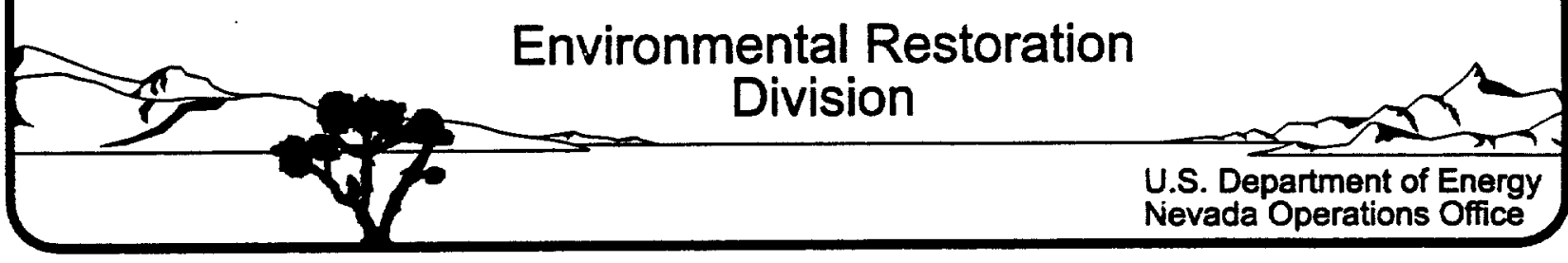




\section{DISCLAIMER STATEMENT}

Reference herein to any specific commercial product, process, or service by trade name, trademark, manufacturex, or otherwise, does not necessarily constitute or imply its endorsement, recommendation, or favoring by the U.S. Government or any agency thereof or its contractors or subcontractors.

\section{AVAILABILITY STATEMENT}

Available for sale to the public from-

U.S. Department of Commerce

National Technical Information Service

5285 Port Royal Road

Springfield, VA 22161

Phone: 800.553.6847

Fax: 703.605.6900

Email: orders@ntis.fedworld.gov

Online ordering: http://www.ntis.gov/ordering.htm

Available electronically at http://www.doe.gov.bridge

Available for a processing fee to U.S. Department of Energy and its contractors, in paper, fromU.S. Department of Energy

Office of Scientific and Technical Information

P.O. Box 62

Oak Ridge, TN 37831-0062

Phone: 865.576.8401

Fax: 865.576.5728

Email: reports@adonis.osti.gov 


\title{
CLOSURE REPORT FOR CORRECTIVE ACTION UNIT 407: ROLLER COASTER RADSAFE AREA, TONOPAH TEST RANGE, NEVADA
}

\author{
Prepared for \\ U. S. Department of Energy \\ Nevada Operations Office \\ Work Performed Under Contract No. \\ DE-AC08-96NV11718
}

Controlled Copy No.:

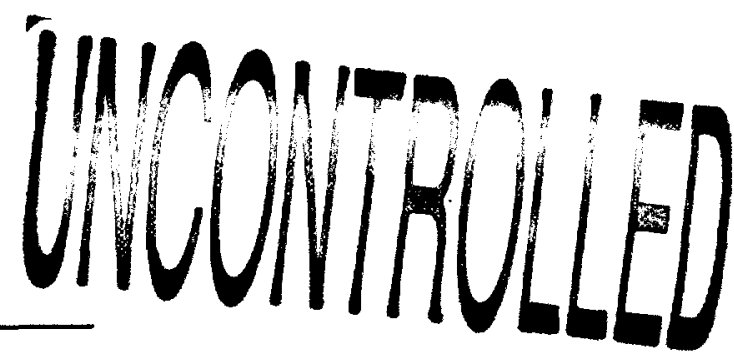

Revision: 1

December 2001 



\section{CLOSURE REPORT FOR CORRECTIVE ACTION UNIT 407: ROLLER COASTER RADSAFE AREA, TONOPAH TEST RANGE, NEVADA}

Approved by: $\frac{\text { Aanct }}{\text { Janed L. Appenzeller-Wing, Project Manager }}$

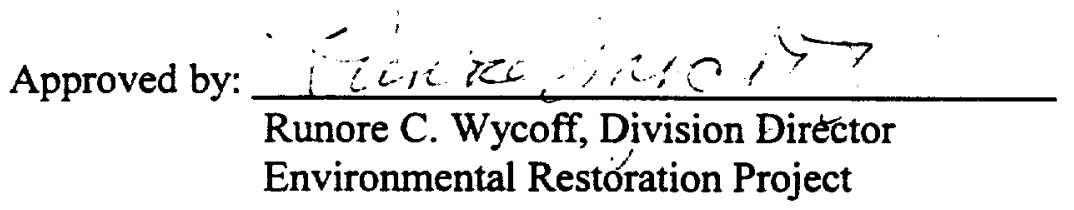

Date: $12 / 12 / 01$

Date: $1.2 / 7,2$ 


\%:

w

列:

w

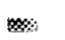

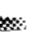




\section{TABLE OF CONTENTS}

ACRONYMS AND ABBREVIATIONS $\ldots \ldots \ldots \ldots \ldots \ldots \ldots \ldots \ldots \ldots$ vii

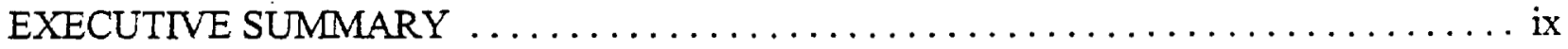

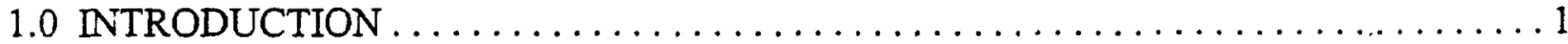

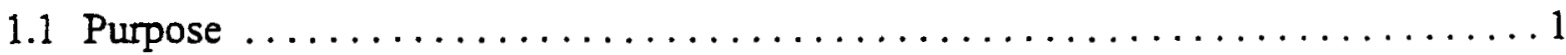

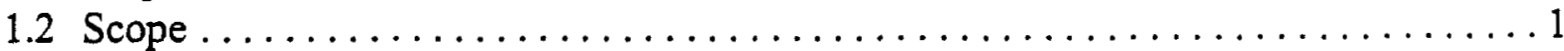

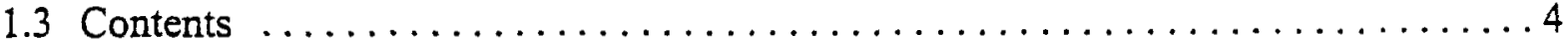

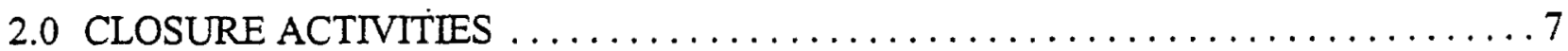

2.1 Description of Prior Corrective Action Activities . . . . . . . . . . . . . . . . . 7

2.2 Description of Corrective Action Activities . . . . . . . . . . . . . . . . . . . 7

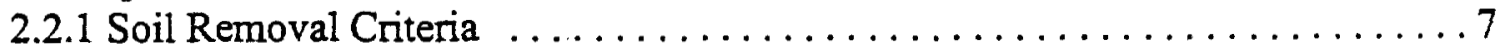

2.2.2 Removal of Surface Impacted Soils . . . . . . . . . . . . . . . . . . 8

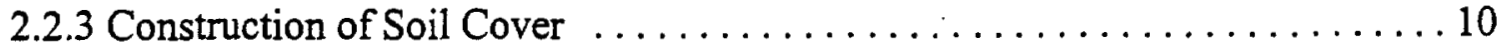

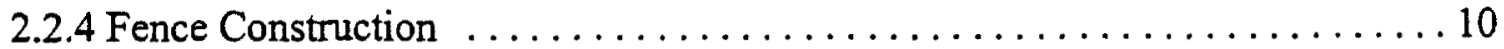

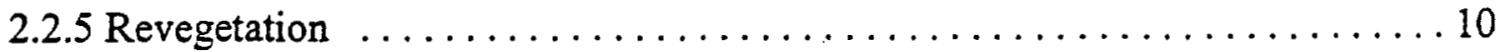

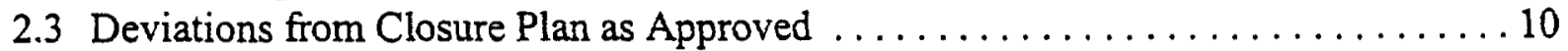

2.4 Corrective Action Schedule as Completed . . . . . . . . . . . . . . . . . . . . 11

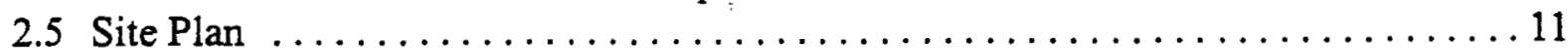

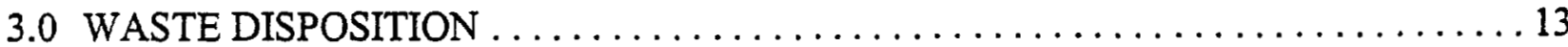

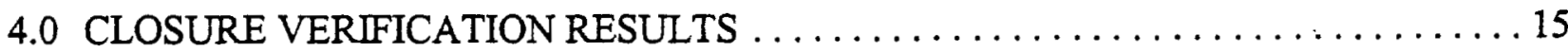

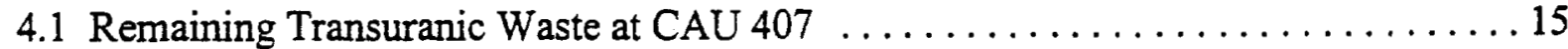

4.2 Land-Use Restrictions . . . . . . . . . . . . . . . . . . . . . . . 16

5.0 CONCLUSIONS AND RECOMMENDATIONS $\ldots \ldots \ldots \ldots \ldots \ldots \ldots \ldots \ldots \ldots \ldots$

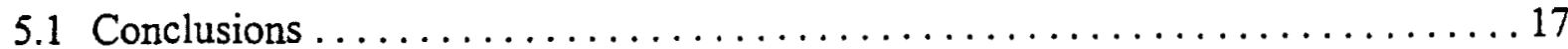

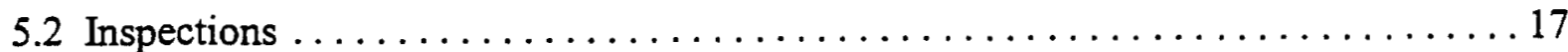

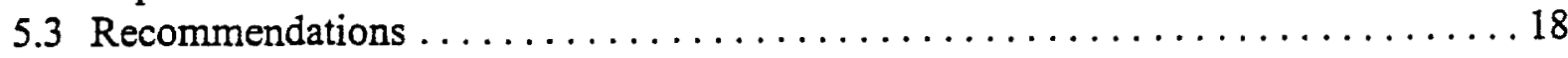

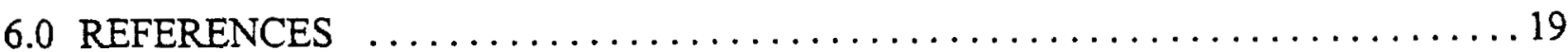

APPENDIX A - HISTORIC PHOTOS

APPENDIX B - CAU 407 AS-BUIL T DRAWINGS

APPENDIX C - PROJECT PHOTOGRAPHS

APPENDIX D - CERTIFICATE OF DISPOSAL

APPENDIX E - STATISTICAL ANALYSIS OF CAU 407 CHARACTERIZATION SAMPLES 


\section{TABLE OF CONTENTS (continued)}

APPENDIX F - USE RESTRICTION FORM

APPENDIX G - CAU 407 INSPECTION CHECKLIST

APPENDIX H - COMMENT RESPONSE DOCUMENTATION

DISTRIBUTION LIST

\section{FIGURES}

Figure 1 - CAU 407 Site Location Map $\ldots \ldots \ldots \ldots \ldots \ldots \ldots \ldots \ldots \ldots \ldots \ldots \ldots \ldots \ldots \ldots$

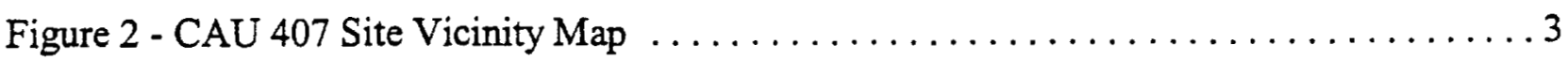

Figure 3 - Locations of Hot Spots Removed from CAU $407 \ldots \ldots \ldots \ldots \ldots$

Figure 4 - CAU 407 Schedule as Completed $\ldots \ldots \ldots \ldots \ldots \ldots \ldots \ldots \ldots \ldots \ldots$

\section{TABLES}

Table 1 - Sample Results for the High Activity Concrete $\ldots \ldots \ldots \ldots \ldots \ldots \ldots \ldots \ldots$

Table 2 - FIDLER Readings Before and After Hot Spot Removal $\ldots \ldots \ldots \ldots \ldots \ldots \ldots$ 


\section{ACRONYMS AND ABBREVIATIONS}

$\mathrm{BN}$

CADD

CAP

CAU

cpm.

CR

DOE/NV

FFACO

FIDLER

ft

gal

$\mathrm{km}$

LLW

m

$\mathrm{mi}$

NDEP

NTS

RCRSA

RWMS

TRU

TTR
Bechtel Nevada

Corrective Action Decision Document

Corrective Action Plan

Corrective Action Unit

counts per minute

Closure Report

U.S. Department of Energy, Nevada Operations Office

Federal Facility Agreement and Consent Order

Field Instrument for the Detection of Low Energy Radiation

feet

gallon

kilometers

low-level waste

meter

miles

Nevada Division of Environmental Protection

Nevada Test Site

Roller Coaster RADSAFE Area

Radioactive Waste Management Site

Transuranic

Tonopah Test Range 


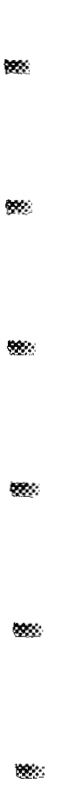
. 


\section{EXECUTIVE SUMMARY}

This closure report provides documentation for the closure of the Roller Coaster RADSAFE Area (RCRSA) Corrective Action Unit (CAU) 407. CAU 407 is located at the Tonopah Test Range (TTR), Nevada, approximately 225 kilometers (140 miles) northwest of Las Vegas, Nevada. The RCRSA was used during May and June of 1963 to decontaminate vehicles, equipment, and personnel from the Double Tracks and Clean Slate tests. The following is the scope of the closure actions implemented for CAU 407 :

- Removal and disposal of surface soils which were over three times background for the area. Soils identified for removal were disposed of at the Area 5 Radioactive Waste Management Site at the Nevada Test Site (NTS). Excavated areas were backfilled with clean borrow soil located near the site.

- A soil cover was constructed over the waste disposal pit area, where subsurface Constituents of Concern remain.

- The site was fenced and posted as an "Underground Radioactive Material" area.

- During the hot spot removals, 4 pieces of concrete were uncovered. One piece had high levels of surface activity. This waste was shipped to the NTS for storage on the TRU pad in Area 5 until it can be disposed of at the Waste Isolation Pilot Project in Carlsbad, New Mexico.

- The cover was prepped and then seeded with plant species native to Area 3 of the TTR.

Based upon the completion of site activities, it is requested that a notice of completion be provided by the Nevada Division of Environmental Protection for CAU 407. 


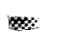

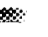




\subsection{INTRODUCTION}

This closure report (CR) provides documentation for the closure of the Roller Coaster RADSAFE Area (RCRSA) Corrective Action Unit (CAU) 407 identified in the Federal Facility Agreement and Consent Order (FFACO) (Nevada Division of Environmental Protection [NDEP] et al., 1996).

CAU 407 is located at the Tonopah Test Range (TTR), Nevada. The TTR is approximately 225 kilometers $(\mathrm{km})$ (140 miles [mi]) northwest of Las Vegas, Nevada (Figure 1). The RCRSA is located on the northeast comer of the intersection of Main Road and Browne's Lake Road, which is approximately $8 \mathrm{~km}(5 \mathrm{mi})$ south of Area 3 (Figure 1). The RCRSA was used during May and June of 1963 to decontaminate vehicles, equipment, and personnel from the Double Tracks and Clean Slate tests. Investigation of the RCRSA was conducted from June through November of 1998. A Corrective Action Decision Document (CADD) (U.S. Department of Energy, Nevada Operations Office [DOE/NV], 1999) was approved in October of 1999.

\subsection{PURPOSE}

The purpose of this CR is to:

- Document the closure activities as proposed in the Corrective Action Plan (CAP) (DOE/NV, 2000).

- Obtain a Notice of Completion from the NDEP.

- Recommend the movement of CAU 407 from Appendix III to Appendix IV of the FFACO.

\subsection{SCOPE}

The following is the scope of the closure actions implemented for CAU 407:

- Removal and disposal of surface soils which were over three times background for the area. Soils identified for removal were disposed of at the Area 5 Radioactive Waste Management Site (RWMS) at the Nevada Test Site (NTS). Excavated areas were backfilled with clean borrow soil located near the site.

- A soil cover was constructed over the waste disposal pit area, where subsurface constituents of concern remain (Figure 2).

- The site was fenced and posted as an "Underground Radioactive Material" area. 

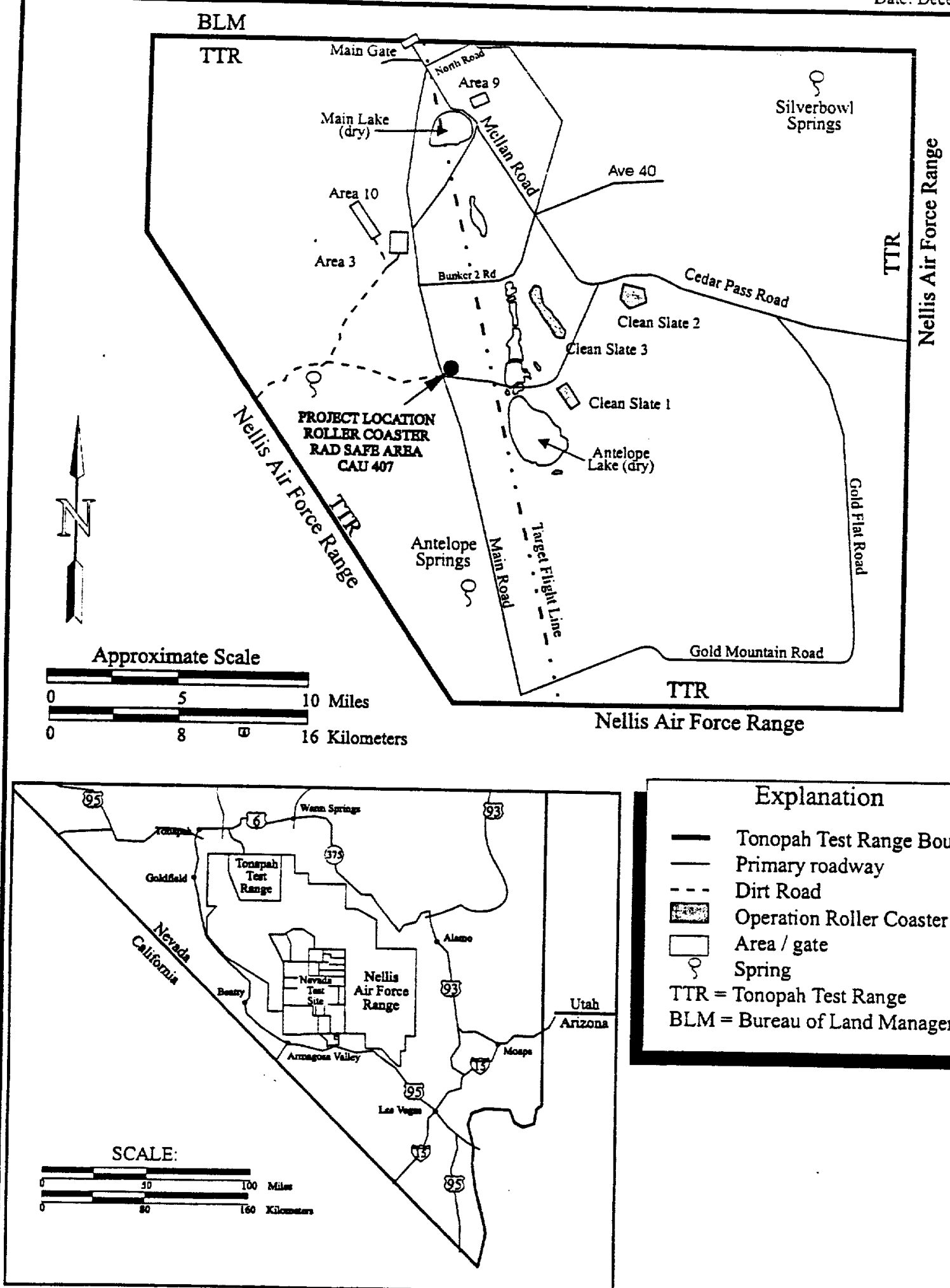

\section{Explanation}

- Tonopah Test Range Boundary

- Primary roadway

- - Dirt Road

Operation Roller Coaster sites

Area / gate

Spring

TTR = Tonopah Test Range

BLM = Bureau of Land Management

FIGURE 1

CAU 407 SITE LOCATION MAP 


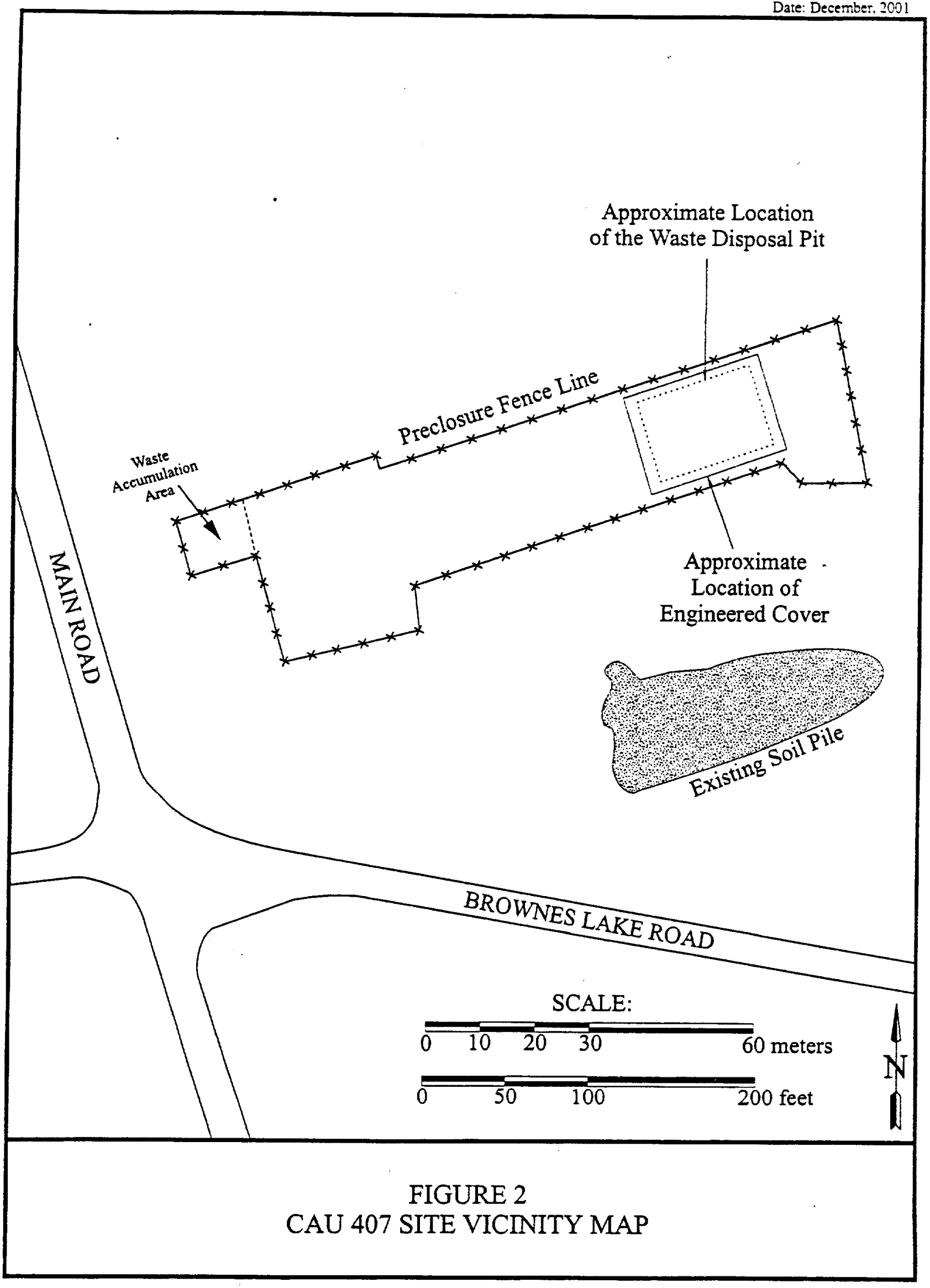


- During the hot spot removals, 4 pieces of concrete were uncovered. One piece had high levels of surface activity. After sampling, the concrete was identified as transuranic (TRU) waste. This waste was shipped to the NTS for storage on the TRU pad in Area 5 until it can be disposed of at the Waste Isolation Pilot Project in Carlsbad, New Mexico.

- The cover was prepped and then seeded with plant species native to Area 3 of the TTR. Closure of CAU 407 was completed using an NDEP-approved CAP (DOE/NV, 2000).

\subsection{CONTENTS}

This $\mathrm{CR}$ is divided into the following sections:

- Section 1.0 - Introduction

- Section 2.0 - Closure Activities

- Section 3.0 - Waste Disposition

- Section 4.0 - Closure Verification Results

- Section 5.0 - Conclusions and Recommendations

- Section 6.0 - References

This report was developed using information and guidance from the following documents:

Bechtel Nevada, 1997, Bechtel Nevada Performance Management Plan, B-A20/96.01, Las Vegas, NV.

Bechtel Nevada, 1999. "Radioactive Waste Tracking, Handling, and Management at the NTS," OP-2151.304, Las Vegas, NV.

Bechtel Nevada, 1998. "General Radiological Control Technician Field Instructions" L-A14.107.H, Revision 1, Las Vegas, NV.

Nevada Division of Environmental Protection, U.S. Department of Energy, and U.S. Department of Defense. 1996. Federal Facility Agreement and Consent Order (FFACO) of 1996.

Nevada Division of Environmental Protection. 2000. Approval of Final Corrective Action Plan (CAP) Corrective Ation Unit (CAU) 407. Roller Coaster RADSAFE Area, TTR Federal Facility Agreement and Consent Order (FFACO). 
U.S. Department of Energy, Nevada Operations Office, 1998. Corrective Action Investigation Plan for the Roller Coaster RADSAFE Area. Corrective Action Unit 407: Nevada Test Site, Nevada, Rev. 0, DOE/NV--503. Las Vegas, NV.

U.S. Department of Energy, Nevada Operations Office, 1999. Corrective Action Decision Document for Corrective Action Unit 407: Nevada Test Site, Nevada, Rev. 0, DOE/NV--567. Las Vegas, NV.

U.S. Department of Energy, Nevada Operations Office, 2000. Corrective Action Plan for Corrective Action Unit 407: Nevada Test Site, Nevada Rev.0, DOE/NV--614. Las Vegas, NV. 


\section{THIS PAGE INTENTIONALLY LEFT BLANK}

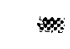

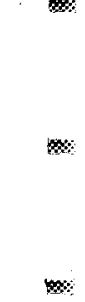

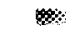

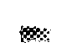

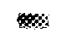

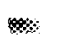

.

㖆

:

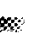

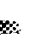

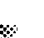




\subsection{CLOSURE ACTIVITIES}

This section of the CR details the specific activities involved in the closure of CAU 407. Based on the site characterization results, the Corrective Action Decision Document for Corrective Action Unit 407: Nevada Test Site, Nevada (CADD) (DOE/NV, 1999) recommended removal of the impacted surface soils and construction of a soil cover over the portion of the site identified as the waste disposal pit. The approved corrective action altemative of close in place, after hot spot removal as specified in the CADD, was implemented.

\subsection{DESCRIPTION OF PRIOR CORRECTIVE ACTION ACTIVITIES}

In 1963 the Roller Coaster RADSAFE waste pit was excavated during follow up to the testing operations (Appendix A). During the excavation, plutonium-contaminated debris, soil, and a steel baseplate were removed from the waste pit and shipped to the Nevada Test Site.

Characterization activities for CAU 407 were conducted in June and July of 1998 . This fieldwork had provisions to clear the "hot spots" of contamination. However, attempts were not completely successful and contamination remained at the surface. Additional "hot spot" removal activities were proposed in the CADD and implemented during the corrective action activities.

\subsection{DESCRIPTION OF CORRECTIVE ACTION ACTIVITIES}

Closure of CAU 407 was completed using the approved CAP for Corrective Action Unit 407: Roller Coaster RADSAFE Area, Tonopah Test Range, Nevada, Revision 0, dated May 2000 (DOE/NV, 2000). The CAP was based on the recommendations presented in the CADD. The CADD was developed from the results of the Corrective Action Investigation Plan (DOE $N$, 1998). Before the closure field activities began, the following prefield activities were completed:

- Preparation of National Environmental Policy Act documentation.

- Preparation of the Site-Specific Health \& Safety Plan and Radiological Work Permit.

- Preparation of the Real-Estate/Operations Permit.

- Preparation of the Field Management Plan.

\subsubsection{Soil Removal Criteria}

The CAIP for CAU 407 originally specified that the PAI for on-site radiological (alpha and beta/gamma) screening was "two times the established daily background". A Record of Technical Change established radiological PALs for the CAU 407 CAIP as "the average activity of 20 background surface samples plus two times the standard deviation of the average activity." 
This change was applied to all samples collected as part of the CAU 407 characterization process.

The CADD for CAU 407 tabulates the analytical results for the samples collected in Appendix A. These results are compared to the background concentrations in McArther and Miller (1989) and U.S. Ecology and Atlan-Tech (1992). The CADD also states, in the evaluation of corrective action alternatives, that surface soils with "contamination greater than 2 to 3 times background or as determined by field screening, whichever is greater, would be excavated to a depth of 6 inches". The three times background criteria was applied only to the identification of "hot spots" based on in-situ soil screening measurements using the FIDLER.

The CAP for the closure of CAU 407 indicated that background readings would be established for the field screening instrumentation and that surface "hot spots" would be removed from areas where the readings exceeded three times the established background. This brought clarification to any ambiguity in the 2 to 3 times background recommendation in the CADD, as approved by the NDEP.

It should be noted that the identification of surface "hot spots" at three-times background, using a FIDLER survey instrument, has no relationship to the field screening levels, or PALs, used for site characterization.

\subsubsection{Removal of Surface Impacted Soils}

The site closure team re-identified the initial surface radiological survey "hot spots" as specified in the CAP. Of the 16 surface locations with elevated gross radiological activity readings identified in the CAP, seven locations were identified with activity readings which exceeded three times background as determined by the Field Instrument for the Detection of Low Energy Radiation (FIDLER). A one minute count established a background reading at $3,500 \mathrm{cpm}$ at a location not impacted by human activity. Three times this value is $10,500 \mathrm{cpm}$ which was used as the clean-up criteria for "hot spot" removal.

Soil was removed from the "hot spot" locations until the criterion of less than three times background was met. The locations of the soil removals are shown in Figure 3. FIDLER readings taken after "hot spot" removal confirmed that no surface soil activity remained that was greater than the three times background criterion. Excavated soil was managed as LLW. Impacted soil was placed into a 55-gallon (gal) drum following Bechtel Nevada (BN) Procedure OP-2151.304, "Radioactive Waste Tracking, Handling, and Management at the NTS," (BN, 1999) and stored temporarily in a waste management area prior to disposal at the Area 5 RWMS on the NTS. Excavations were backfilled with clean fill from a borrow source near the site. 


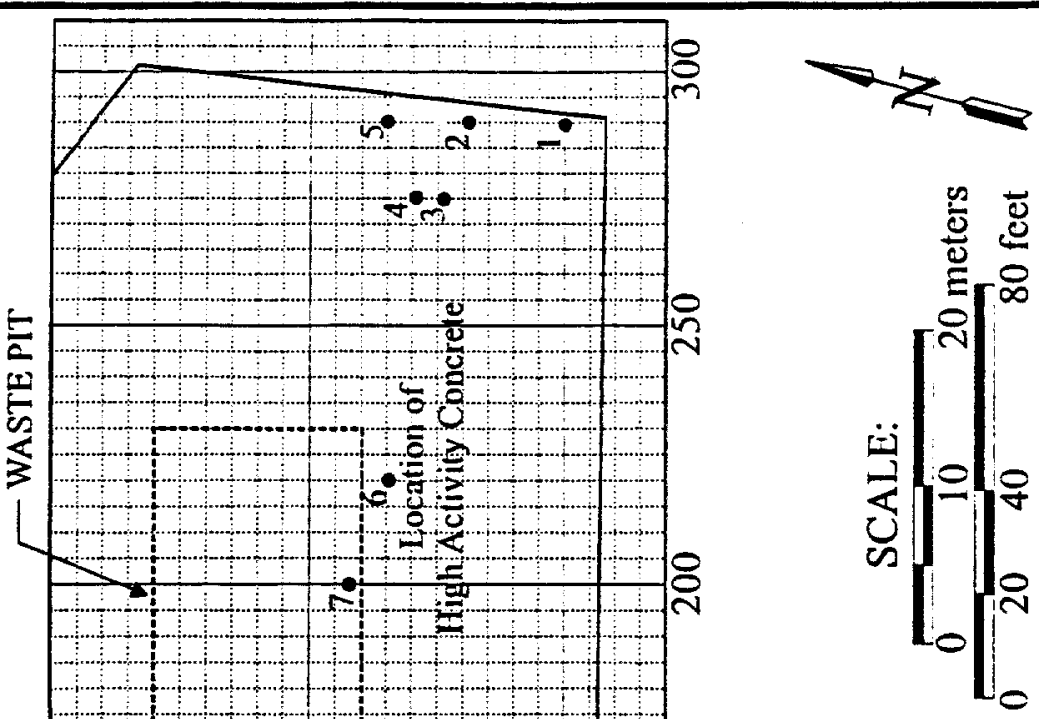


During removal of impacted soils, 4 pieces of impacted concrete were discovered which had a high level of surface activity. These pieces of concrete were isolated for sampling and analysis (see Section 3.0 for analytical results). Sample results indicated that one of the concrete pieces had an acitivity which qualified it as transuranic (TRU) waste. This was previously identified as one of several "hot spots" located during the walkover radiological surveys of CAU 407. The impacted surface soils and debris have been removed and the area re-surveyed to confirm compliance with the CAP.

\subsubsection{Construction of Soil Cover}

The cover design was a 0.6 -meters $(\mathrm{m})$ (2-feet [ft]) thick monolayer of clean fill which was placed over the historic waste pit (Figure 2). The main purpose of this layer was to provide an additional level of protection to the hypothetical future land user from subsurface radionuclides which remain. As-built drawings of the engineered cover are located in Appendix A. Photos of cover construction are included in Appendix B.

\subsubsection{Fence Construction}

Following cover construction, the existing three-strand barbed wire fence was modified (Appendix A). The fence was modified to isolate the cover from intrusion. Additionally, the areas which still potentially contain subsurface radioactive soils were also isolated with fencing. Signs identifying the site as an "Underground Radioactive Material" area were posted on the fencing. The modified site fencing as-built drawing are presented in Appendix A.

\subsubsection{Revegetation}

The primary purpose of seeding the RCRSA cover was to restore the site back to the natural surrounding conditions. The revegetation activity was performed on October 24, 2000. The cover surface was ripped and disced to a depth of approximately $0.4 \mathrm{~m}(1.3 \mathrm{ft})$. After the seed mix was broadcast, straw was applied to the surface as mulch. The seed mixture consisted of a mixture of shallow rooting native species. The fall planting time allows for dormancy-breaking requirements to be met, and that the seed will be in the ground prior to the winter precipitation.

\subsection{DEVIATIONS FROM CLOSURE PLAN AS APPROVED}

The final CAP was approved by NDEP (NDEP, 2000) in May of 2000. The approved closure plan indicated that vegetation, including root balls, would be removed prior to cover construction. The project health physicist requested that the surface soils remain undisturbed to protect site workers from exposure to subsurface radioactivity. All vegetation was removed from the surface, however the root balls were left intact. The fence corners were secured with angle posts rather than excavating and pouring concrete footings at the health physicists request. 
The fence design was also modified slightly from the approved closure plan. Although less than three times the back ground radioactivity, areas of elevated radioactivity remained to the east and west of the cover. The fence was extended to encompass these areas as a best managment practice. The new fence dimensions are located in the as-built drawings (Appendix B). Additionally, the fence comer design and entrance gate design were modified. Cement footings for the barbed wire fencing and the chain-link fence increased costs unnecessarily. A simple barbed wire gate was constructed to allow access to the cover for maintenance purposes. The fence corners were secured with angle posts. The as-built drawings (Appendix B) show the modifications.

\subsection{CORRECTIVE ACTION SCHEDULE AS COMPLETED}

The corrective action began on July 10, 2000. Hot spots removal and cover construction were completed on July 13, 2000. Impacted surface soils were shipped to the Area 5 RWMS for disposal on July 18,2000. Cover revegetation was completed on October 24, 2000. The concrete pieces were shipped to the Area 5 TRU pad for storage on March 6, 2001. Figure 4 provides a detailed schedule of closure activities as completed.

\subsection{SITE PLAN}

The final as-built drawings for the cover are located in Appendix B. 


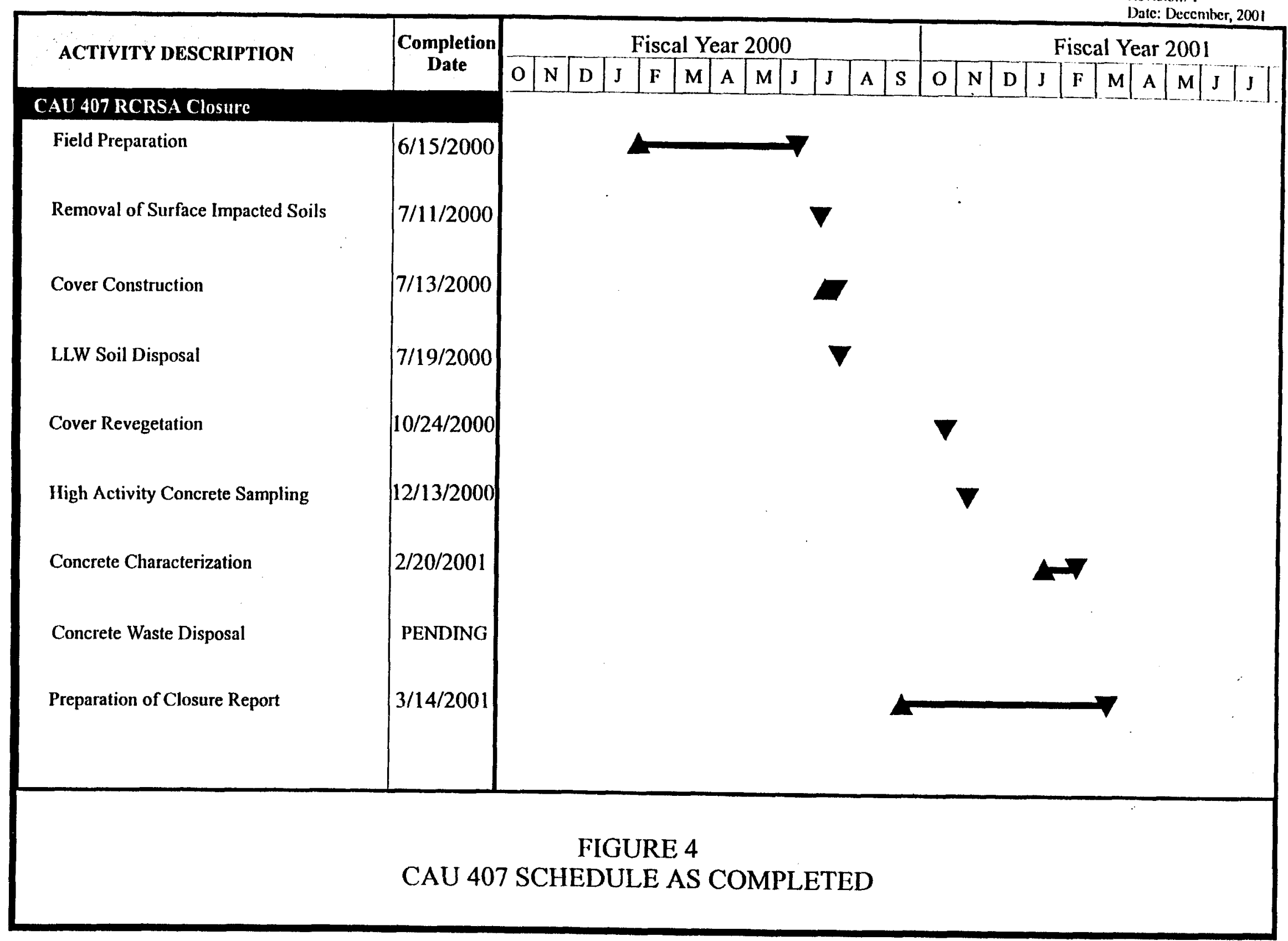




\subsection{WASTE DISPOSITION}

Waste generated from CAU 407 closure activities consisted of radiologically impacted soil and concrete, personal protective equipment, and sanitary trash. Radiologically impacted soil was contained in a 55-gal drum and shipped to the NTS as LLW. The high-activity radiologically impacted pieces of concrete were sampled in order to develop a waste profile. Swipe results from the concrete pieces indicated that the activity was fixed. Sample results indicated that the concrete meets the definition of TRU waste (Table 1). The concrete was shipped to the NTS for storage at the Area 5 TRU pad pending final disposal at the Waste Isolation Pilot Project in Carlsbad, New Mexico. The certificate of disposal for the 55-gal drum of LLW is in Appendix D. All sanitary trash was bagged and disposed of at the TTR dumpster in Area 3.

TABLE 1 - SAMPLE RESULTS FOR THE HIGH ACTIVITY CONCRETE

\begin{tabular}{|c|c|c|}
\hline Sample Identification & Mass of Concrete & Activity of Americium-241 (nCi/g) \\
\hline \hline CAU4070001 & 20 grams & 0.0212 \\
\hline CAU4070002 & 1814 grams & 0.797 \\
\hline CAU4070003 & 60 grams & 2.61 \\
\hline CAU4070004 & 5896 grams & 145.0 \\
\hline
\end{tabular}




\subsection{CLOSURE VERIFICATION RESULTS}

Closure verification for the hot spot removal was accomplished using the FIDLER. The background FIDLER reading was established on native soils not associated with the CAU 407 RADSAFE area. A one minute count established a background reading at 3,500 cpm. Three times this value is $10,500 \mathrm{cpm}$ which was used as the clean-up criteria for "hot spot" removal. Results from the FIDLER before soil removal and after soil removal are presented in Table 1. Closure verification for the soil cover construction was accomplished by surveying the final cover. As-built drawings are presented in Appendix B.

\section{TABLE 2 - FIDLER READINGS BEFORE AND AFTER HOT SPOT REMOVAL}

\begin{tabular}{|c|c|c|}
\hline $\begin{array}{l}\text { Location } \\
\text { Number }\end{array}$ & Initial Reading (cpm x 1000) & Reading after Removal (cpm x 1000) \\
\hline \hline 1 & 64 & 10 \\
\hline 2 & 16 & 9 \\
\hline 3 & 12 & 8.5 \\
\hline 4 & 12 & 9 \\
\hline 5 & 13 & 9.4 \\
\hline 6 & 47 & 10 \\
\hline 7 & 30 & 8.4 \\
\hline
\end{tabular}

\subsection{REMAINING TRANSURANIC WASTE AT CAU 407}

During the CAU 407 site investigation, 78 subsurface samples were collected in and around the waste pit and were submitted for laboratory analysis. Included in this total were 26 subsurface samples collected from the CAU 407 waste pit. The maximum ${ }^{239 / 240} \mathrm{PU}$ concentration detected in these 26 waste pit samples was 5,210 picocuries per gram. Statistical analysis demonstrates that the number of samples collected from the CAU 407 waste pit was sufficient to ensure, at the 99.5 percent confidence level, that the mean TR concentration does not exceed $0.1 \%$ of the transuranic land disposal limit of 100,000 picocuries per gram (Appendix E).

The approved CAU 407 Corrective Action Investigation plan was designed primarily to identify COPCs exceeding PALs in surface and subsurface soils, and to determine the extent of any horizontal and vertical migration of COPCs beyond the site boundaries. These objectives were accomplished. 
A radiological dose analysis was performed to determine the dose to hypothetical future land users from residual radioactivity in the CAU 407 waste pit. The analysis demonstrates that the maximum annual dose is weli below established dose limits.

The plutonium-contaminated piece of concrete was found about 5 feet outside of the CAU 407 waste pit, this material might have bee associated with the 1963 Roller Coaster RADSAFE waste pit excavation. During the excavation, plutonium-contaminated debris, soil, and a steel baseplate were removed from the waste pit and shipped to the Nevada Test Site. Information concerning this operation, provides additional assurance that the waste pit does not currently contain significant amounts of transuranic radionuclides.

\subsection{LAND-USE RESTRICTIONS}

The RCRSA cover and the areas around the cover which contain radiological activity greater than background are fenced from general entry. This area has been posted with signs reading "Underground Radioactive Material." Only authorized personnel may enter for post-closure inspection and repair. The land-use restriction form has been submitted to the U.S. Air Force at the TTR. A copy of the form is located in Appendix F. 


\subsection{CONCLUSIONS AND RECOMMENDATIONS}

\subsection{CONCLUSIONS}

Closure for this site was completed by the following:

- Removal and disposal of surface soils which were over three times background for the area. Soils identified for removal were disposed of at the Area 5 RWMS at the NTS. Excavated areas were backfilled with clean borrow soil located near the site.

- A soil cover was constructed over the waste disposal pit area, where subsurface Constituents of Concern remain.

- The site was fenced and posted as an "Underground Radioactive Material" area.

- During the hot spot removals, a piece of high activity concrete was uncovered. Sampling results indicated that the piece of concrete met the definition of TRU waste. Sampling results and process knowledge support the conclusion that the CAU 407 waste pit does not contain significant amounts of transuranic radionulides.

- The cover was prepped and then seeded with plant species native to Area 3 of the TTR.

The information presented in this report documents that the closure was accomplished in accordance with the approved CAP (DOE/NV, 2000). FIDLER surface readings indicate that the hot spot clean up criteria were met. The as-built drawings demonstrate that the constructed soil cover was built according to specifications (Appendix B). Project photos provide a record of all pertinent activities (Appendix C)

\subsection{INSPECTIONS}

Inspections consist of visually inspecting the cover for signs of erosion, animal burrows, cracks, water ponding, vegetation, and inspecting the fencing and postings. Inspections will be performed twice during the first six months after construction of the cover has been completed. After completion of the quarterly inspections, the cover systems will be inspected and monitored semiannually (twice per year) for the next two years. The frequency after the second year will be determined by NDEP, based on the results of the previous inspections. Any identified maintenance and repair requirements will be remedied within 90 working days of discovery and documented in writing at the time of repair. 
Results of all inspections in a given year will be addressed in a single annual report. The annual report will include the following information:

- Discussion of observations.

- Inspection checklist and maintenance record.

- Conclusions and recommendations.

A copy of each annual report will be submitted to the NDEP. A copy of the inspection checklist is provided in Appendix G.

\subsection{RECOMMENDATIONS}

Based upon the completion of site activities, it is requested that a notice of completion be provided by the NDEP for CAU 407. Upon closure approval, CAU 407 will be promoted from Appendix III to Appendix IV of the FFACO, "Closed Corrective Action Units." 


\subsection{REFERENCES}

BN, see Bechtel Nevada.

Bechtel Nevada, 1997, Bechtel Nevada Performance Management Plan, B-A20/96.01, Las Vegas, NV.

Bechtel Nevada, 1998. "General Radiological Control Technician Field Instructions" L-A14.107.H, Revision 1, Las Vegas, NV.

Bechtel Nevada, 1999. "Radioactive Waste Tracking, Handling, and Management at the NTS," OP-2151.304, Las Vegas, NV.

DOENV, see U.S. Department of Energy, Nevada Operations Office

NDEP, see Nevada Division of Environmental Protection

Nevada Division of Environmental Protection, U.S. Department of Energy, and U.S. Department of Defense. 1996. Federal Facility Agreement and Consent Order (FFACO) of 1996.

Nevada Division of Environmental Protection. 2000. Approval of Final Corrective Action Plan (CAP) Corrective Action Unit (CAU) 407, Roller Coaster RADSAFE Area, TTR Federal Facility Agreement and Consent Order (FFACO).

U.S. Department of Energy, Nevada Operations Office, 1998. Corrective Action Investigation Plan for the Roller Coaster RADSAFE Area. Corrective Action Unit 407: Nevada Test Site. Nevada, Rev. 0, DOENV--503. Las Vegas, NV.

U.S. Department of Energy, Nevada Operations Office, 1999. Corrective Action Decision Document for Corrective Action Unit 407: Nevada Test Site. Nevada, Rev. 0, DOE/NV-567. Las Vegas, NV.

U.S. Department of Energy, Nevada Operations Office, 2000. Corrective Action Plan for Corrective Action Unit 407: Nevada Test Site, Nevada, Rev.0, DOE/NV--614. Las Vegas, NV. 
\%

\%

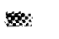

\% 
APPENDIX A

\section{HISTORIC PHOTOS}




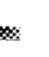

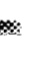

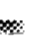

THIS PAGE LEFT INTENTIONALLY BLANK 


\section{Photographs of 1963 CAU 407 Waste Pit Excavation to Recover Double Tracks Steel Plate and Debris}

Attachment $E$ consists of four photographs showing debris and the Double Tracks baseplate being removed from the Roller Coaster Rad Safe Waste Pit.

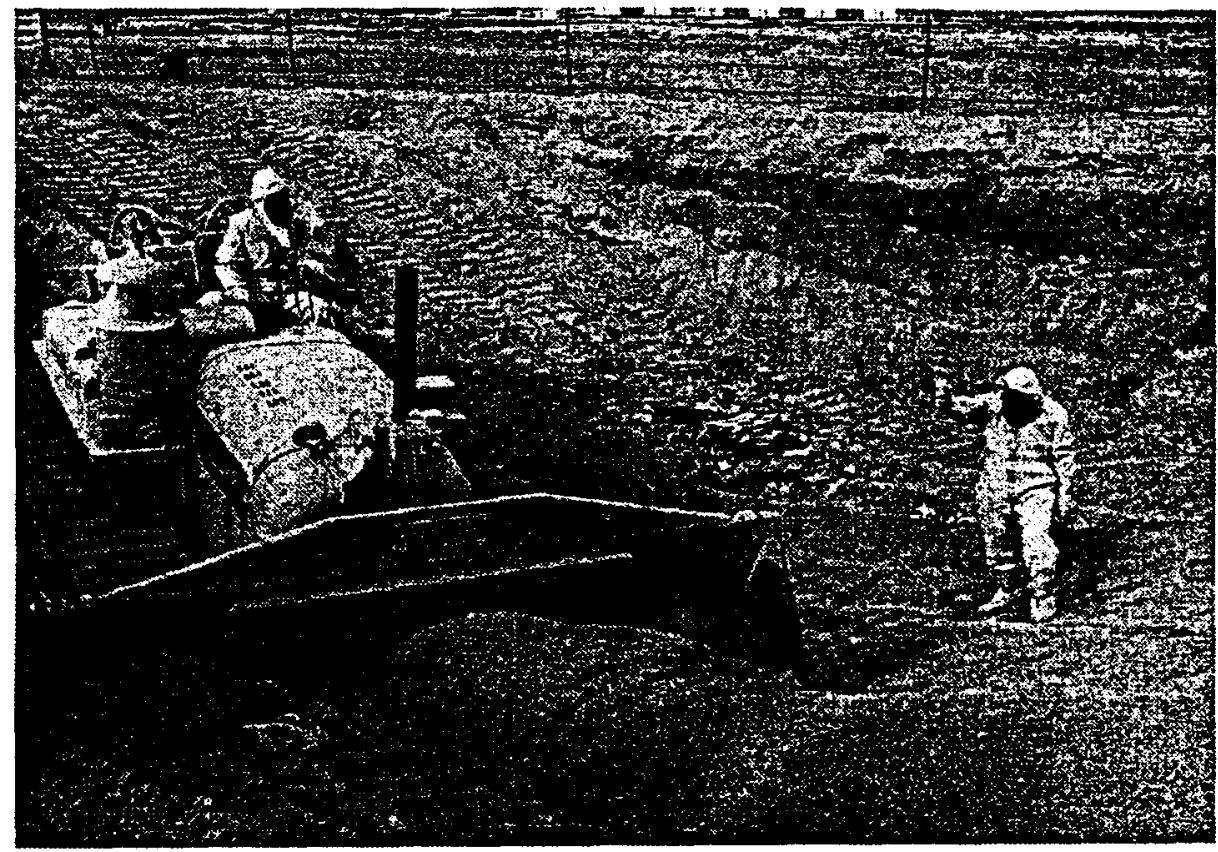

Photo 175-03-TTR-63 shows Radiological Control Technicians during the Roller Coaster Followup Operation directing a bulldozer operator during digging for buried debris at the Rad Safe Waste Pit at Tonopah 
THIS PAGE LEFT INTENTIONALLY BLANK 
4edouol te 1!d ә1seM әjes pey out wou s!ıqop bu!Kues

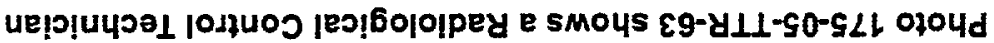

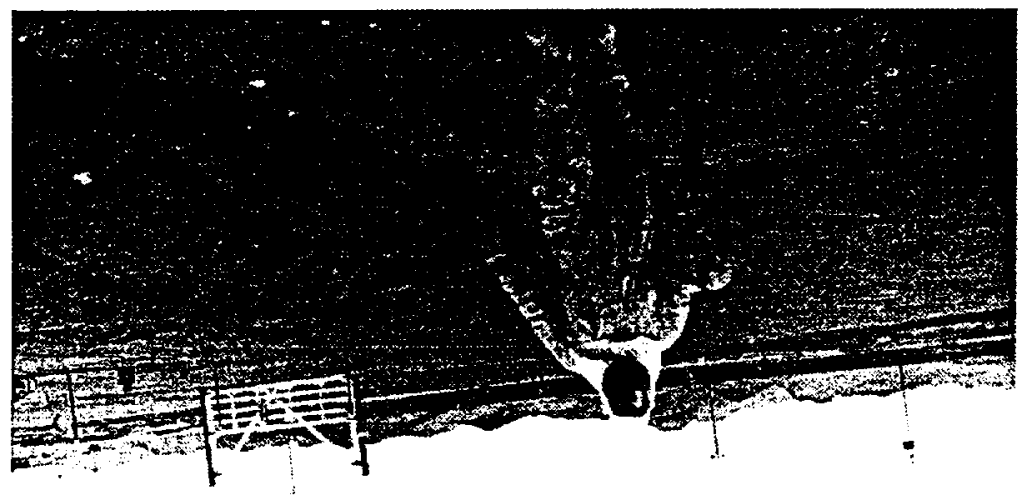

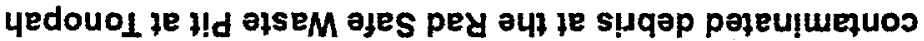
ә|puey of ados bu!sn uo!jesado dnmol|Oy dejseos delloy ou

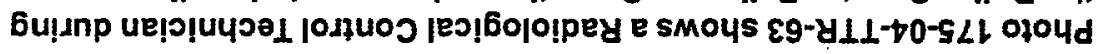

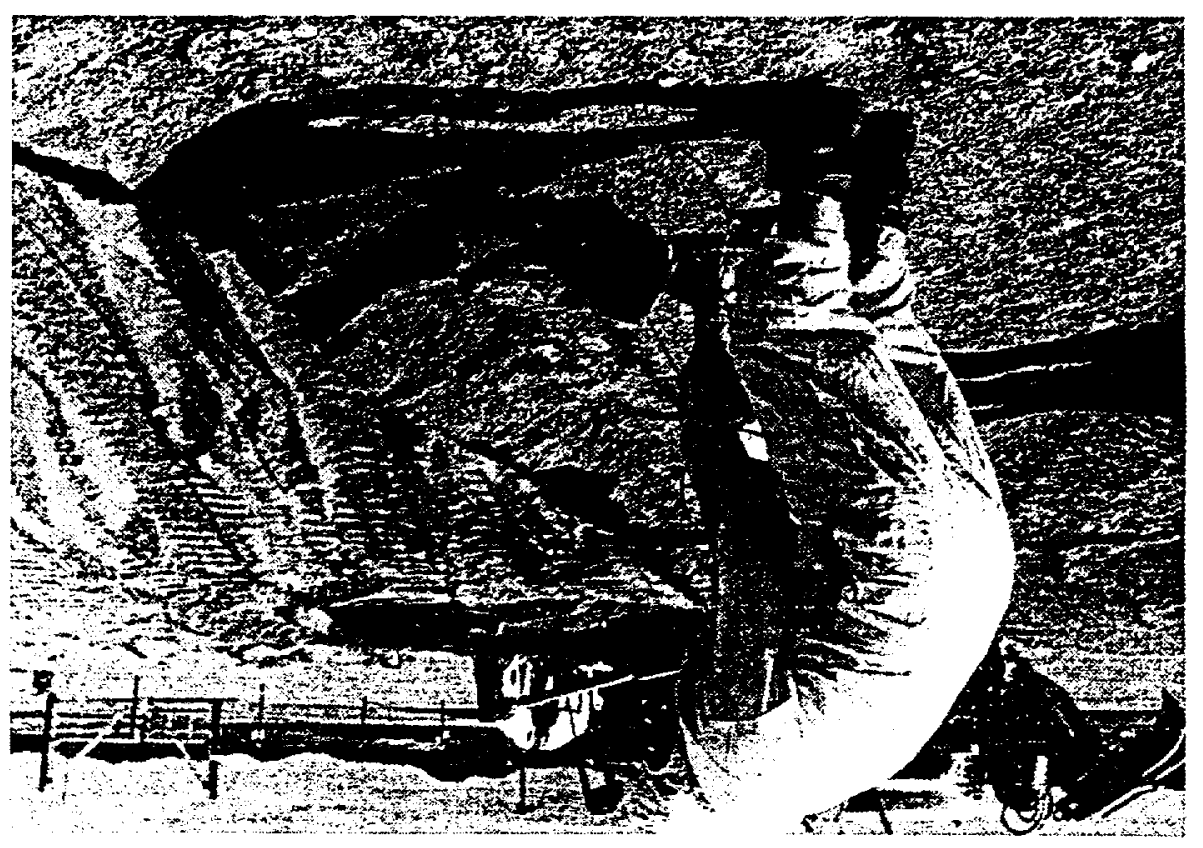


THIS PAGE LEFT INTENTIONALLY BLANK 


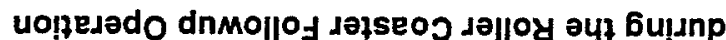

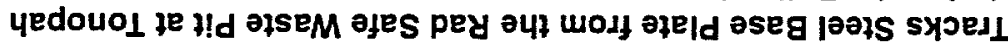

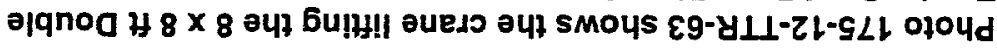

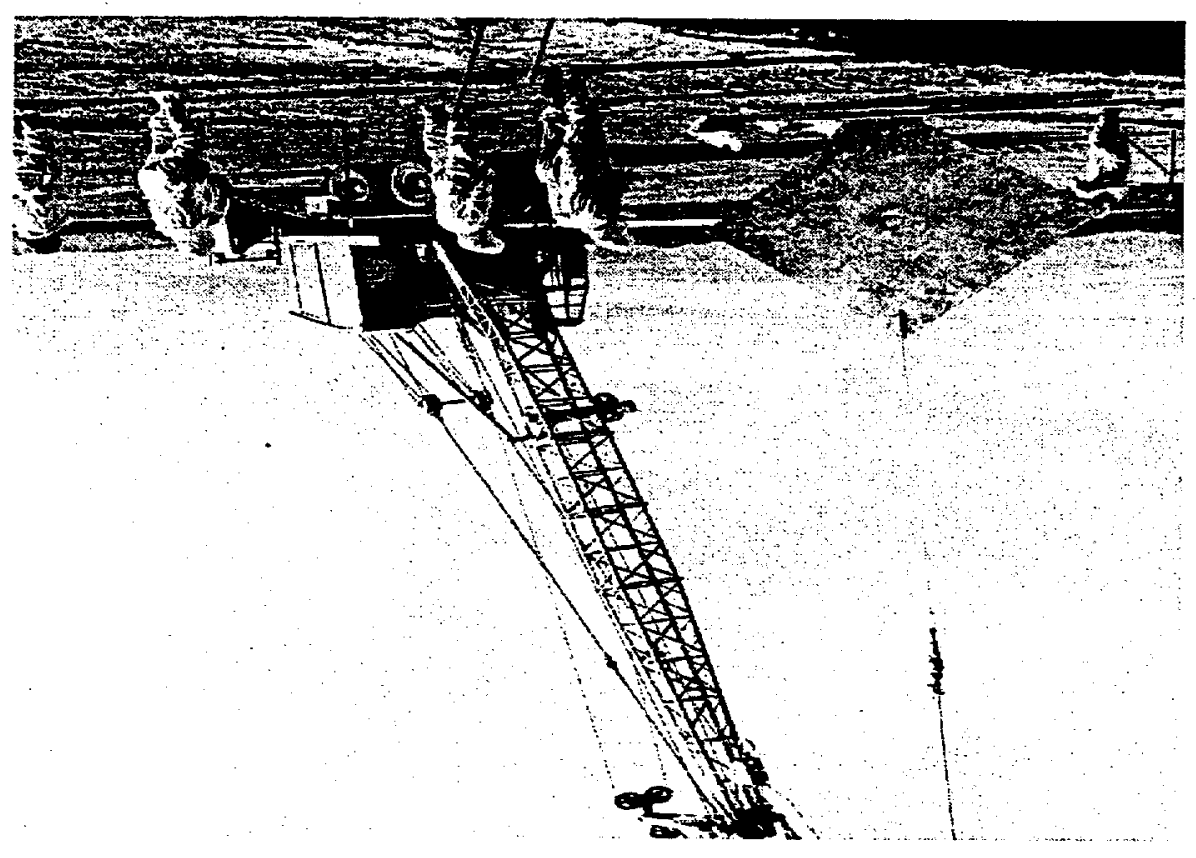




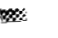




\section{APPENDIX B}

\section{CAU 407 AS-BUILT DRAWINGS}




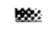




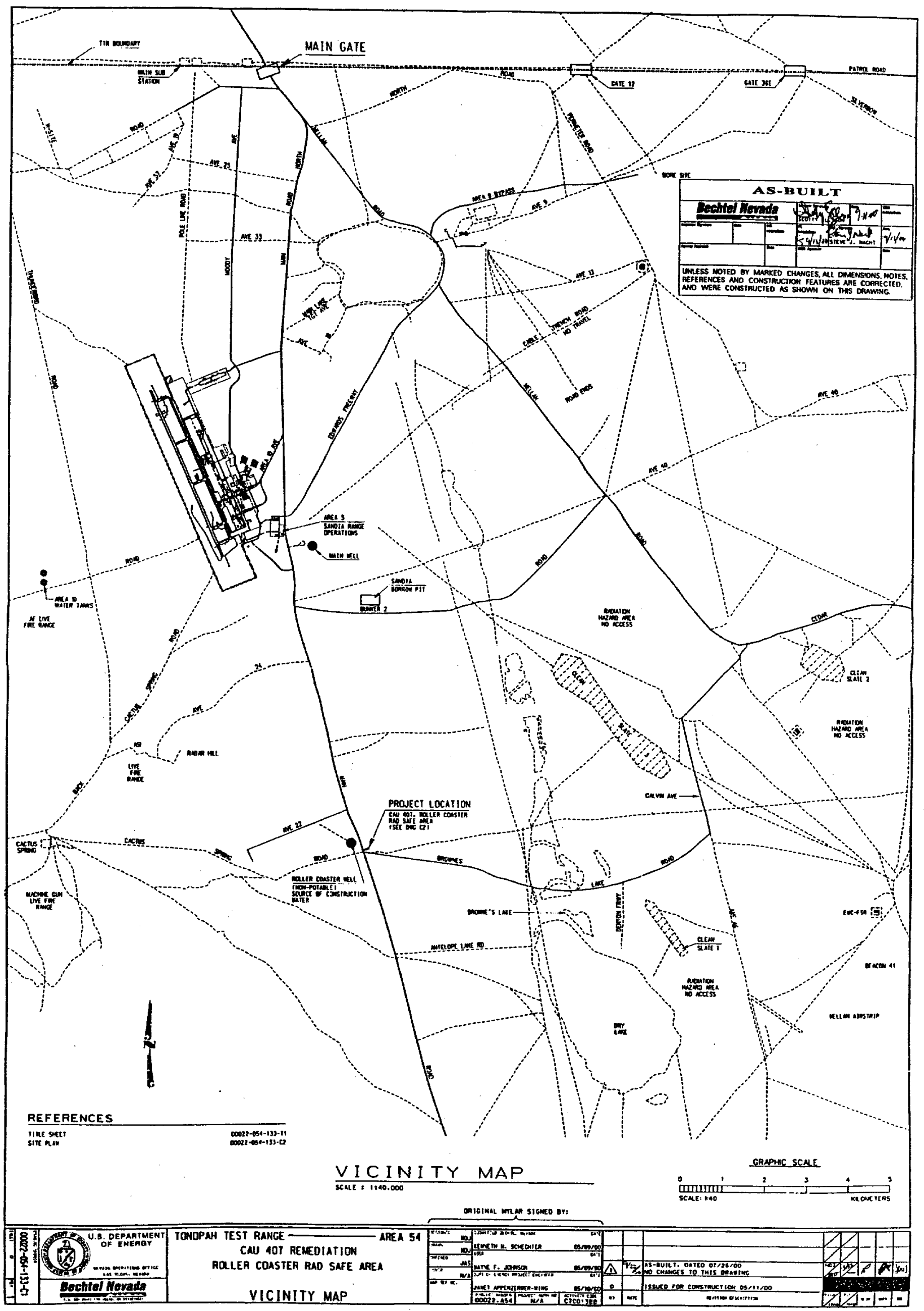




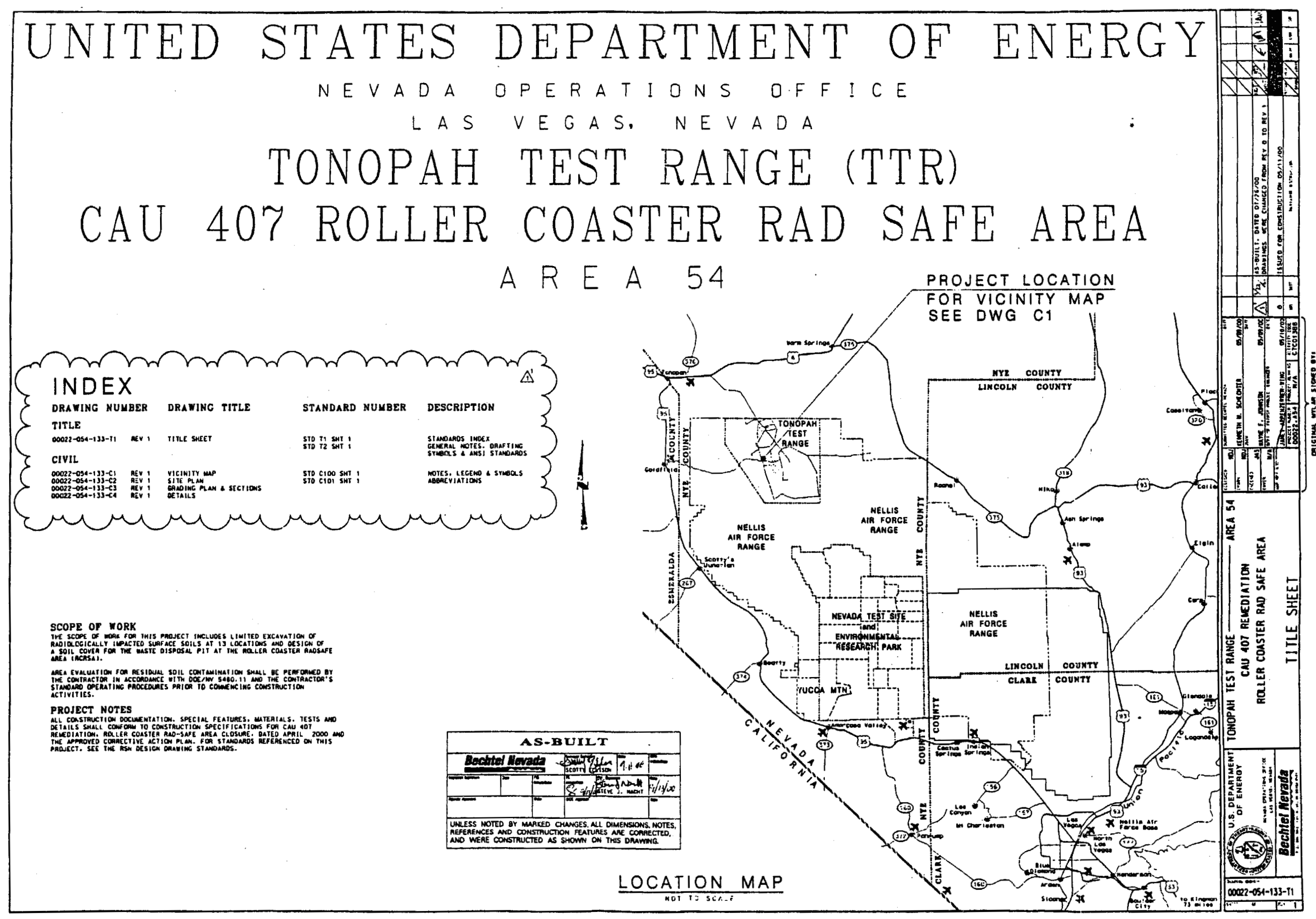




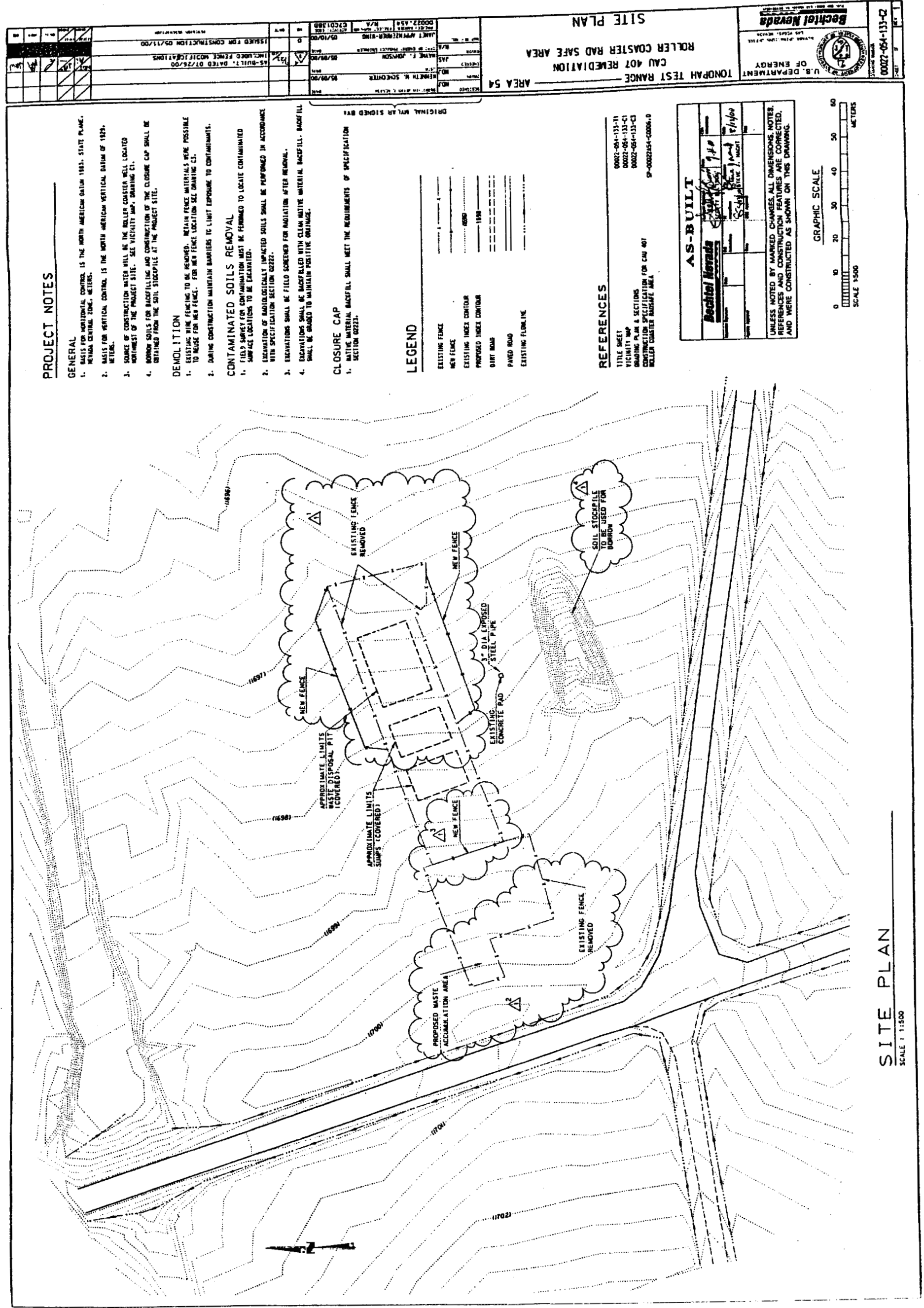




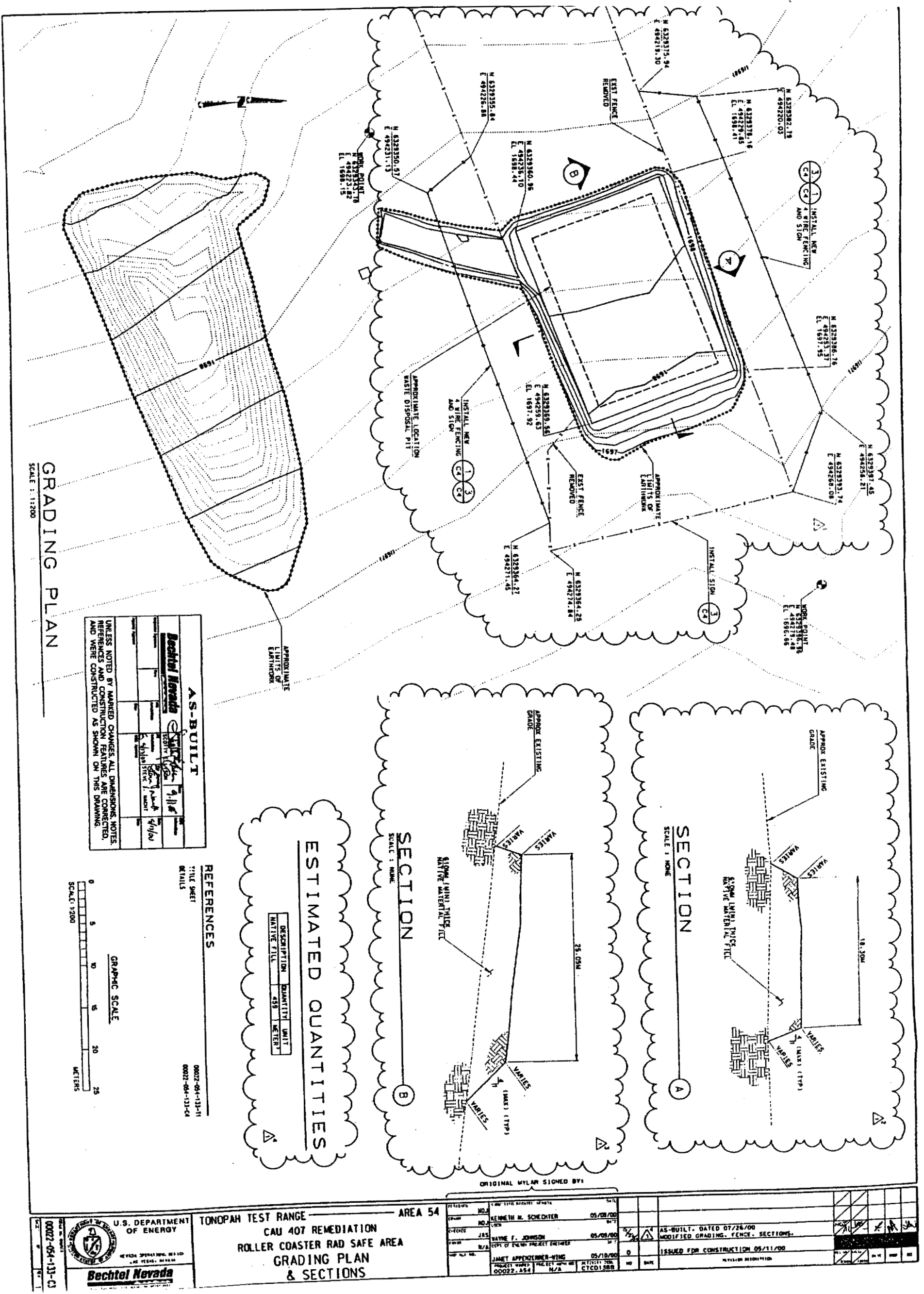




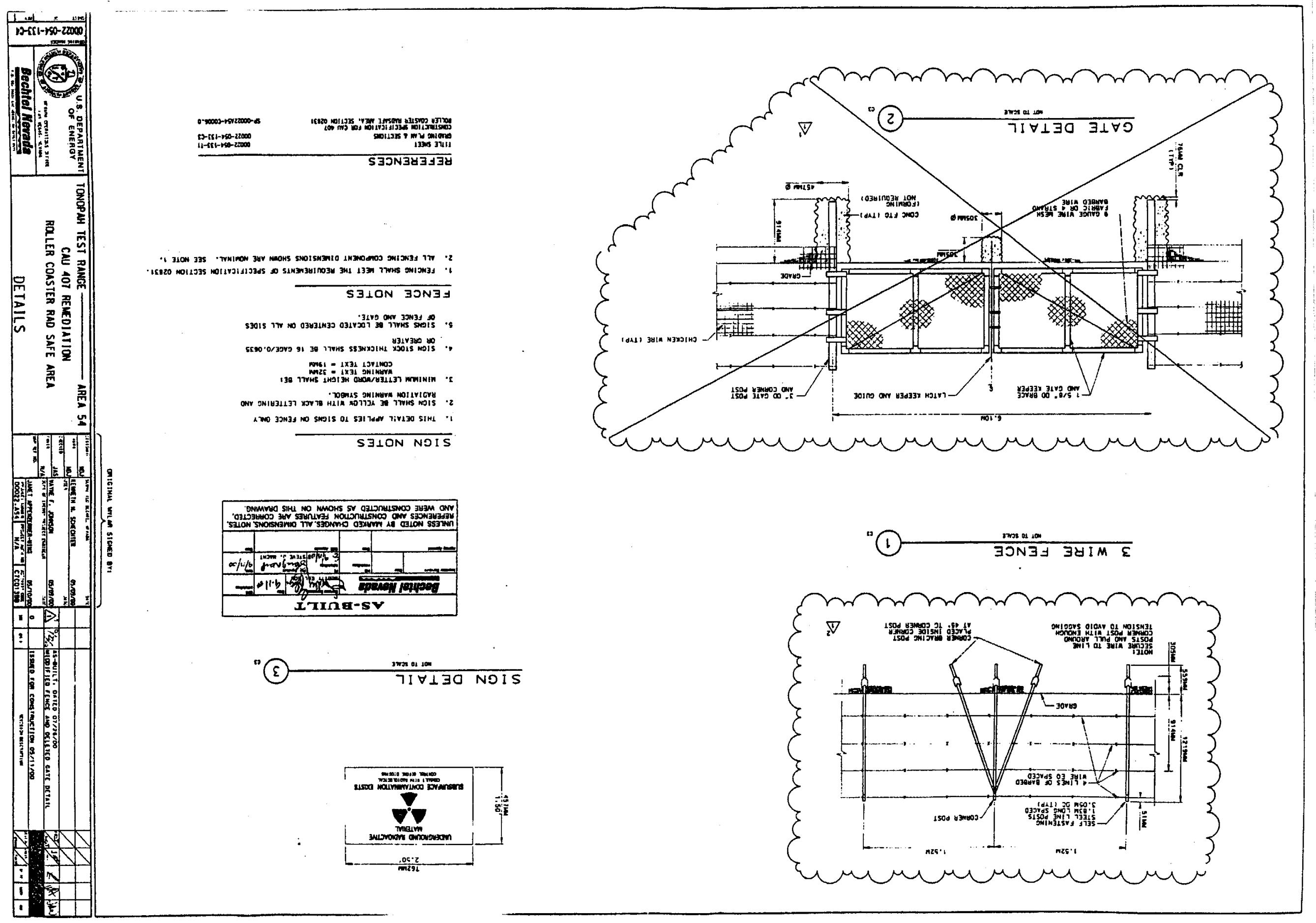


APPENDIX C

PROJECT PHOTOGRAPHS 


\section{HOT SPOT REMOVAL}

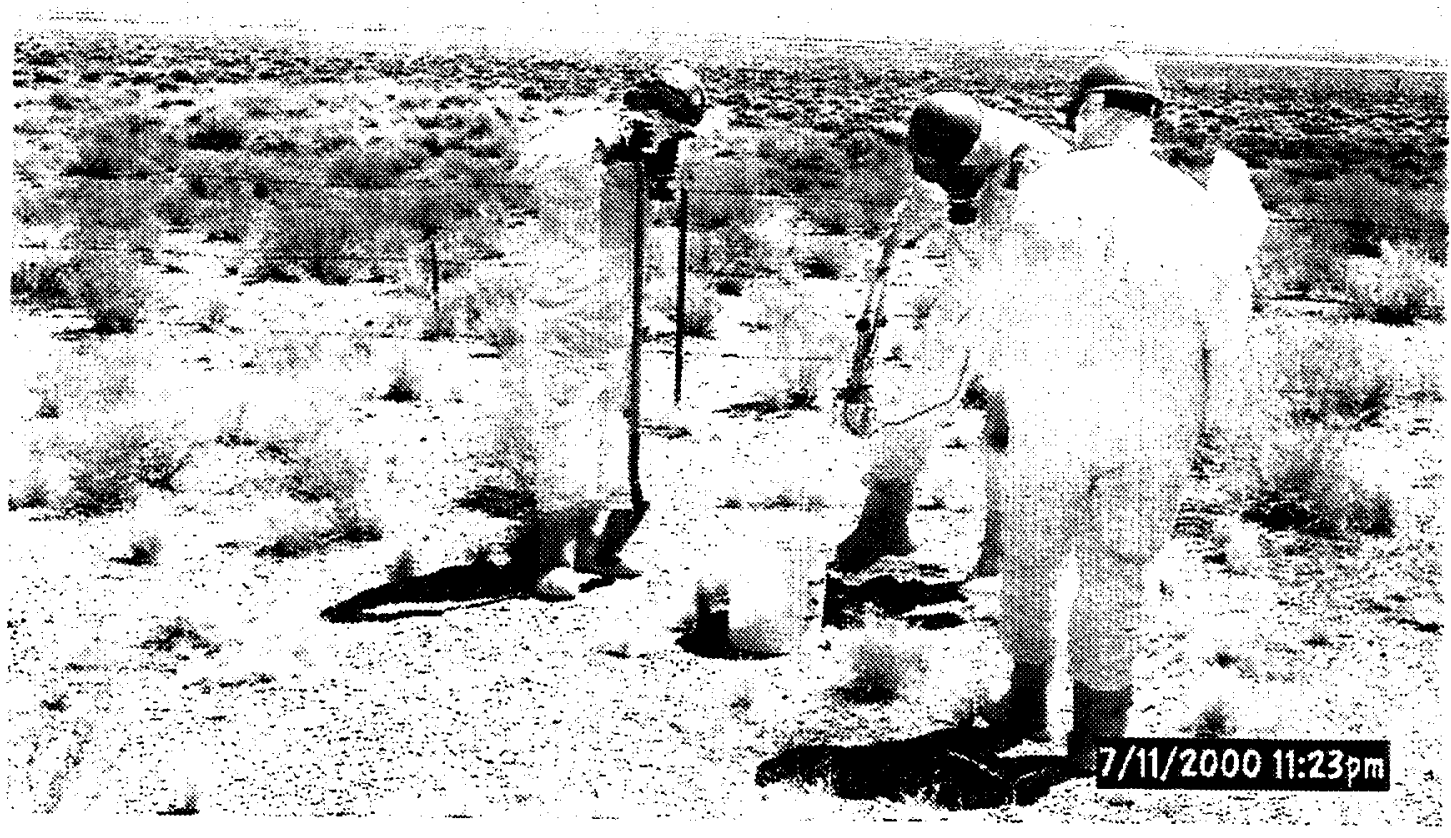

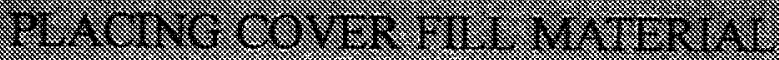

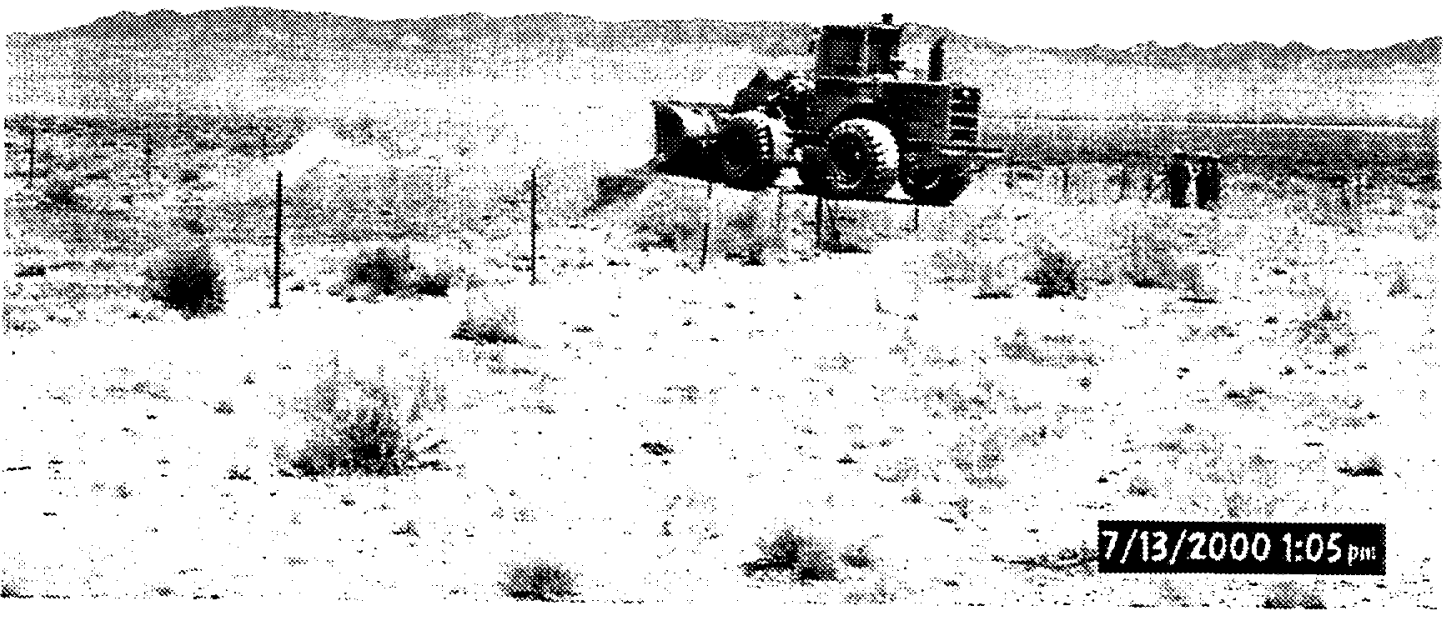

CORRECTIVE ACTION ACTIVITIES 


\section{DISCNNG THE COVER SURFACE}
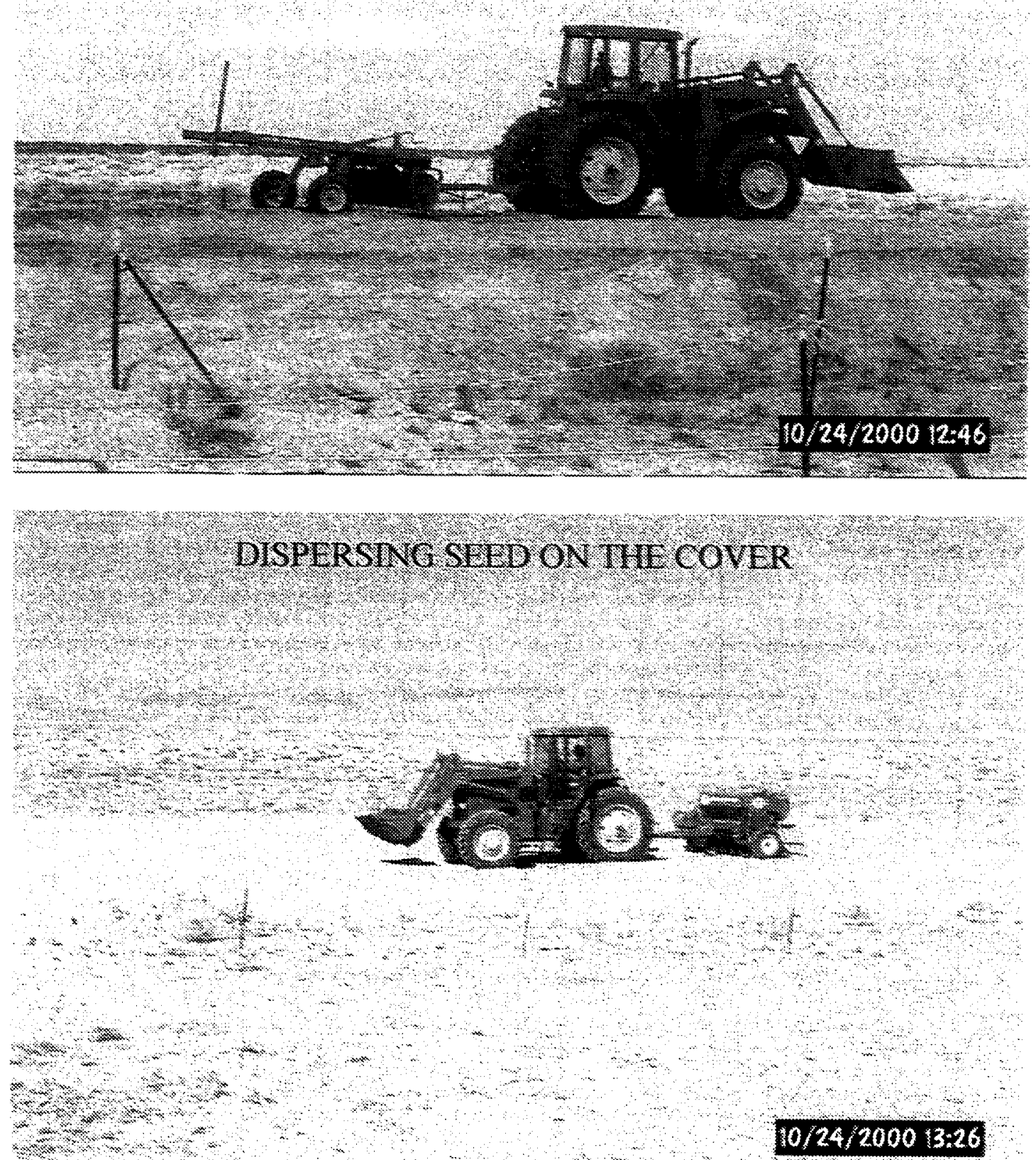

$10 / 24 / 2000 / 3: 26$ 

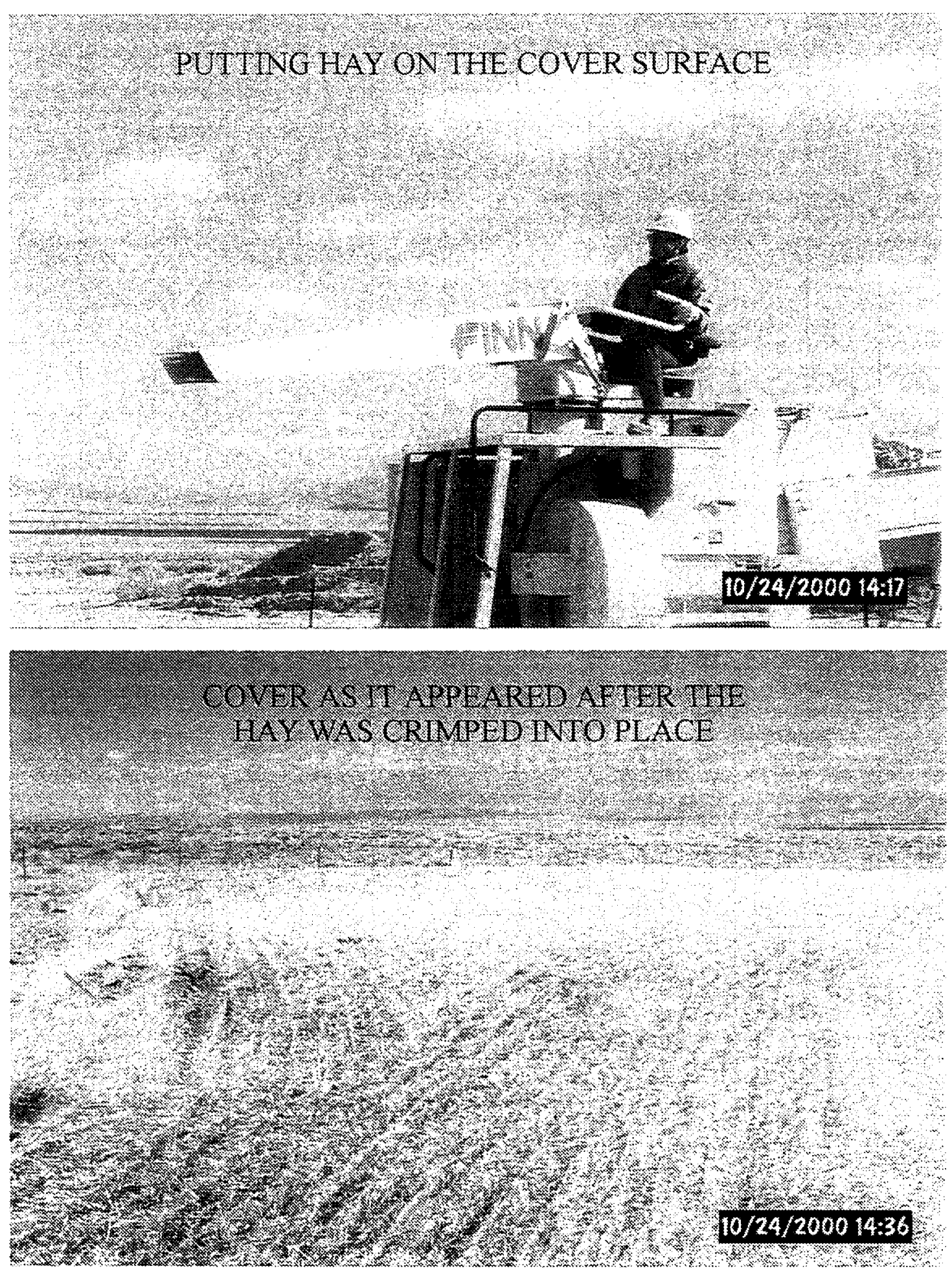

COVER REVEGETATION 
APPENDIX D

\section{CERTIFICATE OF DISPOSAL}


Certificate of Disposal

This is to certify that the, Waste Stream No., LRY5-LLFY00010 container number 194397 was shipped and received at the Nevada Test Site Radioactive Waste Management Site in Area 5 for disposal as stated below.

Stefan Duke

Shipped by
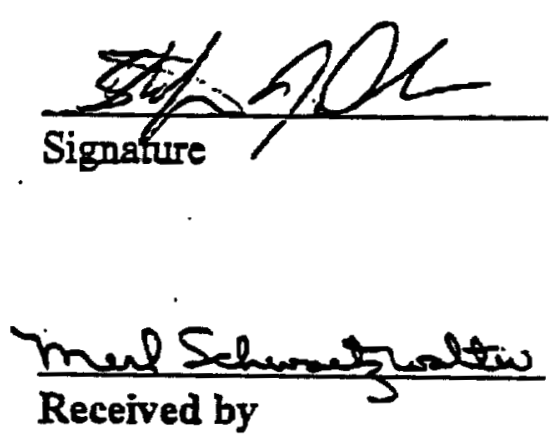

Therese

Signature
Bechtel Nevada Waste Control

Organization

$\frac{\text { Rums }}{\text { Organization }}$
Scientist

Title

Date

$4-18-0)$

Title

tran

$4-18 \cdot 2001$

Date 


\section{APPENDIX E}

\section{STATISTICAL ANALYSIS OF CAU 407 CHARACTERIZATION DATA}




\section{Data Assessment}

The following statistical parameters were calculated using the methods described in Gilbert (1987).

Summary statistics of the radioanalytical results for the 26 soil samples collected from the CAU 407 Waste Pit (Section 13.1, Gilbert, 1987).

Geometric mean concentration of the TR in the 26 soil samples $(\mathrm{pCi} / \mathrm{g})=0.146$ Geometric median concentration of the TR in the 26 soil samples (pCi/g) $=0.031$ Geometric standard deviation of the TR concentration in the 26 soil samples ( $\mathrm{pCi} / \mathrm{g})=45.4$ Geometric variance of the TR concentration in the 26 soil samples $(\mathrm{pCi} / \mathrm{g})=2,057$ Geometric relative standard deviation in the TR concentration in the 26 soil samples $(\mathrm{pCi} / \mathrm{g})=26$

- Sufficient samples were collected from the CAU 407 Waste Pit to ensure, with $>99.5$ percent confidence level, that the mean concentration of transuranic radionuclides in the CAU 407 Waste Pit is less than 0.1 percent of the transuranic waste land disposal limit of $100,000 \mathrm{pCi} / \mathrm{g}$ (Section 4.4.3, Table A2, Gilbert, 1987).

- As noted in Appendix $\mathrm{E}$ of the CAU $407 \mathrm{CADD}$, the maximum dose to the hypothetical future land user will not exceed the established dose limits. 
$-$

$-$

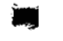

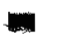

THIS PAGE LEFT INTENTIONALLY BLANK

$-$ 


\section{APPENDIX F}

\section{USE RESTRICTION FORM}


THIS PAGE LEFT INTENTIONALLY BLANK

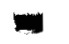

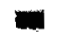

man 


\section{CAU Use Restriction Information}

CAU Number/Description: CAU 407: Roller Coaster RADSAFE Area

Applicable CAS Numbers/Descriptions:CAS TA-23-001-TARC

Contact (organization/project): DOE/NV Industrial Sites Project Manager

Surveyed Area (UTM coordinates; Zone 11, NAD 27): Corners of perimeter fence

N 4,174,452.08m; E $523.716 .57 \mathrm{~m}$. $\mathrm{N} 4,174,448.41 \mathrm{~m} ; \mathrm{E} 523,726.45 \mathrm{~m}$.

N 4,174,418.05m; E 523,733.32m. N 4,174.418.96m; E $523.729 .93 \mathrm{~m}$.

N 4,174,405.12m; E 523,689.67m. N 4,174,410.38m; E523,685.40m.

N 4,174,397.11m; E 523,650.12m. N 4,174,417.83m; E 523.643.29m.

N 4,174,430.44m; E 523,677.75m. N 4,174,437.29m; E 523.678.46m.

Survey Date: Julv 2000 Survey Method (GPS, etc.): Standard Survey Methods

Site Monitoring Requirements: Visual inspection as specified by the closure documentation

Required Frequency (quarterly, annually?): Quarterly the first six months, then biannually (once every six months) for two vears. After two vears the frequency will be determined by the NDEP based on previous inspection results.

If Monitoring Has Started, Indicate Last Completion Date: N/A

\section{Use Restrictions}

The future use of any land related to this Corrective Action Unit (CAU), as described by the above surveyed location, is restricted from any DOE or Air Force activity that may alter or modify the containment control as approved by the state and identified in the CAU Closure Report or other CAU documentation unless appropriate concurrence is obtained in advance.

Comments: Radiological contamination is present in the soil a minimum of approximately 3.0 meters ( 10 feet) below ground surface within the above surveved location. Refer to the Closure Report more details and additional information on the condition of the site and anv monitoring and/or inspection requirements.

Submitted By:

Date:

cc with copy of survey map:

CAU Files (2 copies) 


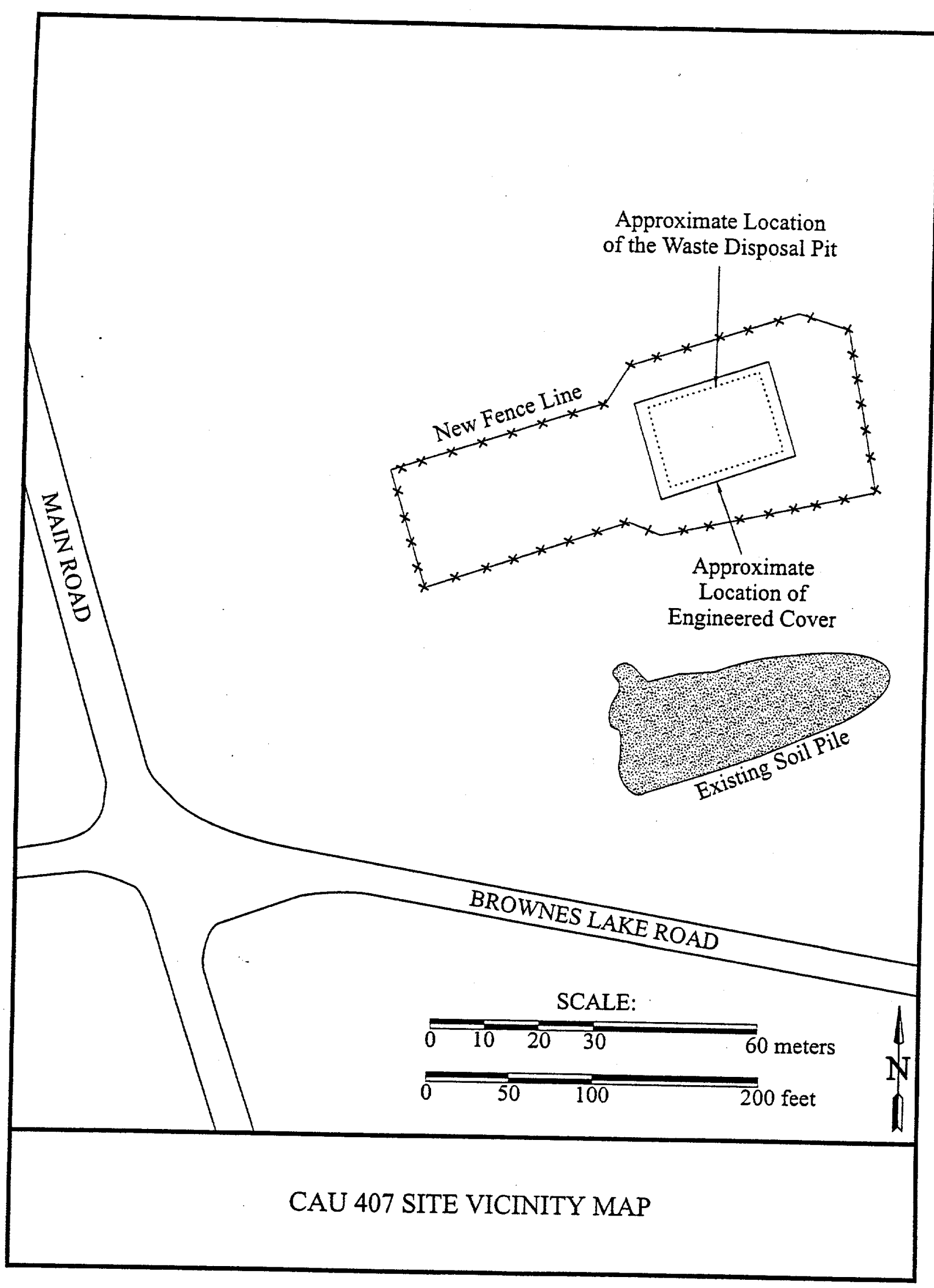




\section{DEPARTMENT OF THE AIR FORCE 99TH CIVIL ENGINEER SQUADRON (ACC) NELLIS AIR FORCE BASE, NEVADA 89191}

Ms. Eloisa Hopper

$23 \mathrm{Feb} 01$

Chief, Environmental Management Flight

4349 Duffer Dr., Suite 1601

Nellis AFB NV 89191-7007

Ms. Runore C. Wycoff

Director, Environmental Restoration Division

DOE Nevada Operations Office

P.O. Box 98518

Las Vegas NV 89193-8518

RECORDATION OF CORRECTIVE ACTION UNIT (CAU) 407

Nellis Air Force Base (Nellis) has recorded the U.S. Department of Energy's (DOE) Use Restriction Information for Corrective Action Unit (CAU) 407. The information was placed in the Geographic Information System at the Range Management Office, Nellis.

Please contact me at $652-4123$ if you have any questions.

Sincerely

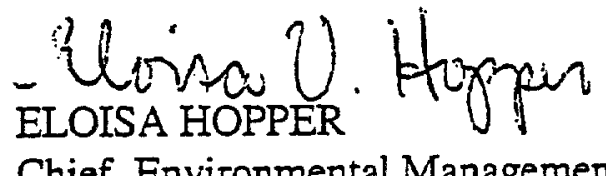

Chief, Environmental Management Flight

cc:

NDEP

HQ AWFC RMO/RMI

HQ AWFC/JAV 


\section{APPENDIX G}

\section{CAU 407 INSPECTION CHECKLIST}


w

THIS PAGE LEFT INTENTIONALLY BLANK

\%

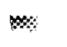

w 


\begin{tabular}{||l|l|}
\hline ROLLER COASTER RADSAFE AREA, POST-CLCSURE MONITORING CHECKLIST \\
\hline Date of Last Inspection: & Reason for Last Inspection: \\
\hline Responsible Agency: & Project Manager: \\
\hline Inspection Date: & \\
\hline inspector (name, title. organization): & \\
\hline Assistant inspector (name, tite, organization): \\
\hline
\end{tabular}

A. GENERAL INSTRUCTIONS

1. All checklist items must be completed and detailed comments made to document the results of the site inspection. The completed checklist is part of the field record of the inspection. Additional pages should be used as necessary to ensure that a complete record is made. Attach the additional pages and number all pages upon completion of the inspection.

3. Any checklist line item marked by an inspector in a SHADED BOX, must be fully explained or an appropriate reference to previous reports provided. The purpose of this requirement is to provide a written explanation of inspector observations and the inspector's rationale for conclusions and recommendations. Explanations are to be placed on additional attachments and cross-referenced appropriately. Explanations, in addition to narrative, will take the form of sketches, measurements, annotated site maps.

4. The site inspection is a walking inspection of the entire site including the perimeter and sufficient transects to be able to inspect the entire surface and all features specifically described in this checklist.

5. A standard set of color $35 \mathrm{~mm}$ photographs (or equivalent) is required. In addition, all anomalous features or new features (such as changes in adjacent area land use) are to be photographed. A photo log entry will be made for each photograph taken.

6. This unit will be inspected biannually with formal reporting to the Nevada Division of Environmental Protection to be done annually. The annual report will include an executive summary, this inspection checklist with field notes and photo log attached, and recommendations and conclusions.

\begin{tabular}{|l|l|l|l|}
\hline B. PREPARATION (TO be completed prior to site visit) & YES & NO & EXPLANATION \\
\hline 1. Site as-built plans and site base map reviewed. & & \\
\hline 2. Previous inspection reports reviewed. & & \\
$\begin{array}{l}\text { a. Were anomalies or trends detected on previous inspections? } \\
\text { b. Was maintenance performed? }\end{array}$ & & & \\
\hline $\begin{array}{l}\text { 3. Site maintenance and repair records reviewed. } \\
\text { a. Has site repair resulted in a change from as-built conditions? }\end{array}$ & & & \\
b. Are revised as-builts available that reflect repair changes? & & & \\
\hline C. SITE INSPECTION (To be completed during inspection) & YES & NO & EXPLANATION \\
\hline
\end{tabular}

1. Adjacent off-site features within watershed areas.

a. Have there been any changes in use of adjacent area?

b. Are there any new roads or trails?

c. Has there been a change in the position of nearby washes?

d. Has there been lateral excursion or erosion/deposition of nearby washes?

e. Are there new drainage channels?

f. Change in surrounding vegetation?

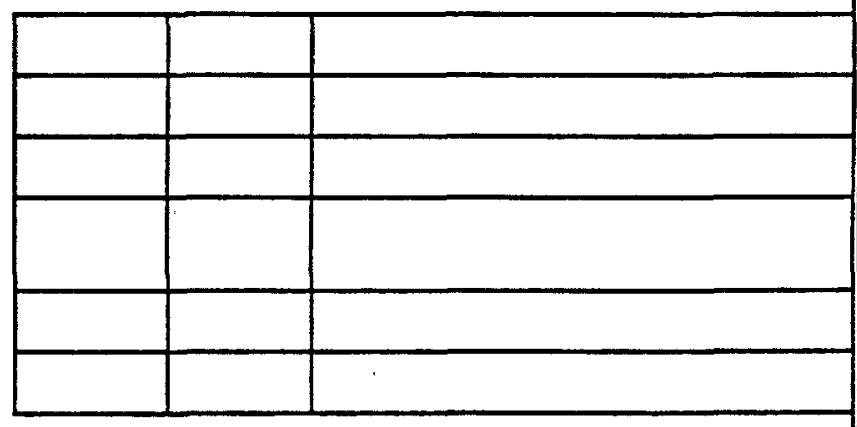

2. Security fence, signs.

a. Displacement of fences, site markers, boundary markers, or monuments?

b. Have any signs been damaged or removed? (Number of signs replaced: )

c. Were gates in working condition?

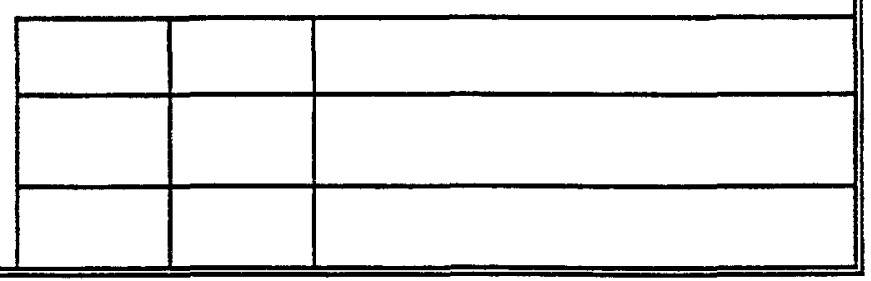




\begin{tabular}{|l|l|l|l|l|}
\hline ROLLER COASTER RADSAFE AREA, POST-CLOSURE MONITORING CHECKLIST \\
\hline 3. Waste Unit cover. \\
a. is there evidence of setting? \\
b. Is there cracking? \\
c. is there evidence of erosion around the cap (wind or water)? \\
d. is there evidence of animal burrowing? \\
e. Do natural processes threaten to integrity of any cover or site \\
marker? \\
f. Other?
\end{tabular}

4. Vegetative cover.

a. Is perimeter fence or mesh fencing damaged?

b. Is there evidence of horses or rabbits on site?

c. Is organic mulch adequate to prevent erosion?

d. Are weedy annual plants present? If yes, are they a problem?

e. Are seeded plant species found on site?

f. Is there evidence of plant mortality?

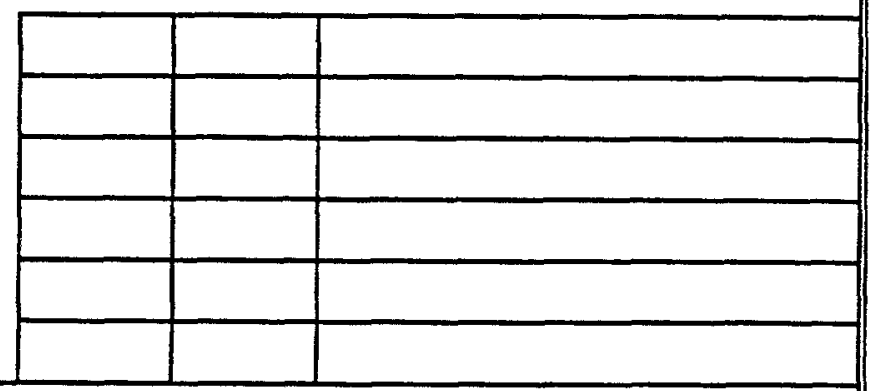

5. Photo Documentation

a. Has a photo log been prepared?

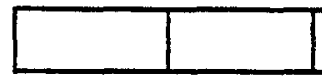

c. Number of photos exposed ( 1

\section{FIELD CONCLUSIONS}

1. Is there an imminent hazard to the integrity of the unit? (Immediate report required)

Person/Agency to whom report made:

2. Are more frequent inspections required?

3. Are existing maintenance/repair actions satisfactory?

4. Is other maintenance/repair necessary?

5. Is current status/condition of vegetative cover satisfactory?

6. Rationale for field conciusions:

\section{E. CERTIFICATION}

I have conducted an inspection of the Cactus Spring Waste Trenches, CAU 426, at the TTR in accordance with the Post-Closure Monitoring Plan (see Closure Report) as recorded on this checktist, attached sheets, field notes, photo logs, and photographs.

Chief Inspector's Signature:

Printed Name: 


\section{APPENDIX H}

\section{COMMENT RESPONSE DOCUMENTATION}




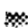

*

THIS PAGE LEFT INTENTIONALLY BLANK

$\%$

$\infty$

$\%$

\%

\%

. 


\section{DOCUMENT REVIEW SHEET}

Document Title/Number: Draft Closure Report for Corrective Action Unit 407: Roller Coaster RADSAFE Area, Tonopah Test Range, Nevada

Document Date: December 2000

Revision Number: 0

Originator/Organization: Nevada Division of Environmental Protection

Date Comments Due: January 28, 2000

Reviewer/Organization: Michail D. McKinnon / NDEP

\begin{tabular}{||c|c|c|c||}
\hline $\begin{array}{l}\text { Comment } \\
\text { Number/ } \\
\text { Location }\end{array}$ & Type & Comment & Comment Response \\
\hline \hline 1. Appendix C & $\mathrm{M}$ & $\begin{array}{l}\text { In Appendix C (Waste Manifests), the BN } \\
\text { Hazardous Material Shipping Order lists the } \\
\text { weight of the disposed soil as 68 pounds. } \\
\text { The Straight Bill of Lading lists the weight } \\
\text { as 568 pounds. These two weights should } \\
\text { agree. }\end{array}$ & $\begin{array}{l}\text { The Hazardous Material Shipping Order } \\
\text { should have listed the weight of the } \\
\text { disposed soil as 568 pounds. The } \\
\text { Straight Bill of Lading is correct. The } \\
\text { Hazardous Material Shipping Order has } \\
\text { been corrected in the file. }\end{array}$ \\
\hline
\end{tabular}


*

$=$

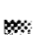

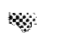

wa

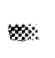


Document Title/Number: Closure Report for Corrective Action Unit 407: Roller Coaster RADSAFE Area, Tonopah Test Range, Nevada

Document Date: April, 2000

Revision Number: 0

Originator/Organization: Nevada Division of Environmental Protection

Date Comments Due: May, 2000

Reviewer/Organization: Michael D. McKinnon / NDEP 


\begin{tabular}{||l|l|l|l|l||}
\hline $\begin{array}{c}\text { Comment } \\
\text { Number/ } \\
\text { Location }\end{array}$ & Type & Comment & Comment Response. & Accept \\
\hline \hline 1. General & M & $\begin{array}{l}\text { There are discrepancies between the } \\
\text { Preliminary Action Level (PAL) for } \\
\text { radioactivity specified in the CAIP, the } \\
\text { CADD, and the CR. The CAIP originally } \\
\text { specified, “...two time the established daily } \\
\text { background..., but was changed to, “...the } \\
\text { average activity of 20 background surface } \\
\text { samples plus two times the standard } \\
\text { deviation of the average activity..."(Record } \\
\text { of Technical Change, 8/17/98). The CADD } \\
\text { indicates, “...Contaminated surface soil } \\
\text { greater than 2 to 3 times background...will } \\
\text { be excavated to a depth of 6 in...... The CR } \\
\text { documents removal of soil which exceeds 3 } \\
\text { times background. DOE/NV needs to } \\
\text { reconcile the discrepancies in the } \\
\text { radioactivity PAL among these documents. }\end{array}$ & $\begin{array}{l}\text { A section was added (2.2.1 Soil Removal } \\
\text { screening criteria during the different } \\
\text { phases of this project. }\end{array}$ & Yes \\
\hline
\end{tabular}

a. Comment Types: $M=$ Mandatory $S=$ Suggested

Page 2 of 3 


\begin{tabular}{|c|c|c|c|c|}
\hline $\begin{array}{l}\text { Comment } \\
\text { Number/ } \\
\text { Location }\end{array}$ & Type & Comment & Comment Response. & Accept \\
\hline 2. Section 2.1 .1 & M & $\begin{array}{l}\text { Removal of Subsurface Impacted Soils, } \\
\text { refers to radioactivity background of } 3,500 \\
\text { counts per minute (CPM) as established by } \\
\text { the FIDLER. The twenty individual } \\
\text { FIDLER readings of radiation background as } \\
\text { well as the average and standard deviation of } \\
\text { the average should also be indicated. This } \\
\text { will enable a comparison of the original PAL } \\
\text { for radiation with the activity remaining at } \\
\text { the surface (prior to canping) }\end{array}$ & $\begin{array}{l}\text { See above response. Additional detail } \\
\text { was provided in Section } 2.2 .2 \text { and } \\
\text { Section } 4.0 \text { explaining how background } \\
\text { was established prior to "hot spot" } \\
\text { removal. }\end{array}$ & Yes \\
\hline 3. General & M & $\begin{array}{l}\text { At the FFACO Quarterly meeting held on } \\
2 / 7 / 01, \text { NDEP expressed concerm that } \\
\text { transuranic (TRU) waste might still be } \\
\text { located in the waste pit of CAU } 407 \text {. Since } \\
\text { TRU waste which is below the surface will } \\
\text { not be detected by a surface FDLER survey, } \\
\text { DOE/NV has not demonstrated in this } \\
\text { closure report that all TRU waste has been } \\
\text { removed from CAU } 407 \text {. This issue was not } \\
\text { addressed in previous reviews because } \\
\text { DOE/NV did not identify TRU waste at this } \\
\text { site until after the draf CR had been } \\
\text { anproved. }\end{array}$ & $\begin{array}{l}\text { A section was added ( } 4.1 \text { Remaining } \\
\text { Transuranic Waste at CAU 407) to assess } \\
\text { the probability that transuranic waste still } \\
\text { may be present within the waste pit. } \\
\text { Also section } 2.1 \text { (Description of Prior } \\
\text { Closure Activities) was added. These } \\
\text { activities were not discussed in the } \\
\text { previous report. }\end{array}$ & Yes \\
\hline
\end{tabular}

a. Comment Types: $M=$ Mandatory $S=$ Suggested

Page 3 of 3 
\%

新

THIS PAGE LEFT INTENTIONALLY BLANK

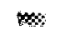

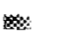

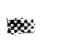




\section{DISTRIBUTION LIST}




\section{DISTRIBUTION LIST}

*Provide copy of initial distribution or Revision 0; remainder of list gets Revision 0 if approved without changes. The entire list receives Revision 1 , if issued.

\section{Nevada Division of Environmental Protection}

Paul Liebendorfer

2 (Controlled)*

Bureau of Federal Facilities

Division of Environmental Protection

333 W. Nye Lane, Room 13B

Carson City, NV 89706-0866

Mike McKinnon

1(Controlled)*

Bureau of Federal Facilities

Division of Environmental Protection

Sawyer State Building

555 E. Washington, Suite 4300

Las Vegas, NV 89101-1049

\section{U.S. Department of Energy}

Janet Appenzeller-Wing

1(Uncontrolled)*

Environmental Restoration Division

U.S. Department of Energy, Nevada Operations Office

P.O. Box $98518 \mathrm{M} / \mathrm{S} 505$

Las Vegas, NV 89193-8518

Kevin Cabble

Environmental Restoration Division

1(Uncontrolled)*

U.S. Department of Energy, Nevada Operations Office

P.O. Box $98518 \mathrm{M} / \mathrm{S} 505$

Las Vegas, NV 89193-8518

Sabrina Lawrence

1 (Controlled)*

Environmental Restoration Division

U.S. Department of Energy, Nevada Operations Office

P.O. Box $98518 \mathrm{M} / \mathrm{S} 505$

Las Vegas, NV 89193-8518 


\section{DISTRIBUTION LIST (Continued)}

\section{U.S. Department of Energy (continued)}

U.S. Department of Energy

Office of Scientific and Technical Information

P.O. Box 62

Oak Ridge, TN 37831-0062

U.S. Department of Energy

Nevada Operations Office

Technical Information Resource Center

P.O. Box 98518, M/S 505

Las Vegas, NV 89193-8521

Manager, Southern Nevada

FFACO Public Reading Room

P.O. Box $98521 \mathrm{M} / \mathrm{S}$ NLV040

Las Vegas, NV 89193-8521

Manager, Northern Nevada

FFACO Public Reading Room

Nevada State Library and Archives Federal Publications

100 North Stewart Street

Carson City, NV 89701-4285
1(Uncontrolled, electronic copy)

1(Uncontrolled)

1(Controlled) \& 1(Uncontrolled)

1(Uncontrolled)

\section{Bechtel Nevada}

Correspondence Control

1(Uncontrolled)*

Bechtel Nevada

P.O. Box $98521 \mathrm{M} / \mathrm{S}$ NLV008

Las Vegas, NV 89193-8521

Environmental Management Library

1(Uncontrolled)*

Bechtel Nevada

P.O. Box 98521, M/S NLV080

Las Vegas, NV 89193-8521 


\section{DISTRIBUTION LIST (Continued)}

\section{Bechtel Nevada (continued)}

Ann Heidema

1(Uncontrolled)*

Bechtel Nevada

P.O. Box 98521 M/S NLV022

Las Vegas, NV 89193-8521

Thomas Fitzmaurice

1(Uncontrolled)*

Bechtel Nevada

P.O. Box 98521 M/S NTS306

Las Vegas, NV 89193-8521

Wayne Johnson

1(Uncontrolled)*

Bechtel Nevada

P.O. Box $98521 \mathrm{M} / \mathrm{S}$ NTS306

Las Vegas, NV 89193-8521

Steve Nacht

1 (Uncontrolled)*

Bechtel Nevada

P.O. Box $98521 \mathrm{M} / \mathrm{S}$ NTS306

Las Vegas, NV 89193-8521

\section{IT Corporation}

Lynn Kidman

1 (Uncontrolled)*

IT Corporation

P.O. Box 93838

Las Vegas, NV 89193-8521

Jeff Johnson

1 (Uncontrolled)*

IT Corporation

P.O. Box 93838

Las Vegas, NV 89193-8521 
IT FFACO Support Office

IT Corporation

P.O. Box 93838

Las Vegas, NV 89193-8521

U.S. Air Force

U.S. Air Force DOE Liason Office

DOE/Nevada Operations Office

P.O. Box 98518, M/S 505

Las Vegas, NV 89193-8518

Eloisa V. Hopper

U.S. Aire Force

$99 \mathrm{ABW} / \mathrm{EM}$

4349 Duffer Dr., Suite 1601

Nellis AFB, NV 89191-7007

Major Roger Schofield

U.S. Aire Force

AWFC RMO/RML99

3770 Duffer Dr.

Nellis AFB, NV 89191-7007
1 (Uncontrolled)*

1 (Uncontrolled)*

3 (Controlled)*

1 (Uncontrolled)* 